University of Rhode Island

DigitalCommons@URI

Open Access Master's Theses

1962

\title{
Chick Embryo Lethal Orphan Virus (CELO) as a Tissue Culture Contaminant
}

Dharam Vir Ablashi

University of Rhode Island

Follow this and additional works at: https://digitalcommons.uri.edu/theses

\section{Recommended Citation}

Ablashi, Dharam Vir, "Chick Embryo Lethal Orphan Virus (CELO) as a Tissue Culture Contaminant" (1962). Open Access Master's Theses. Paper 811. https://digitalcommons.uri.edu/theses/811

This Thesis is brought to you for free and open access by DigitalCommons@URI. It has been accepted for inclusion in Open Access Master's Theses by an authorized administrator of DigitalCommons@URI. For more information, please contact digitalcommons-group@uri.edu. 


\title{
636.50896 Ablot
}

\author{
CHICK FMBRYO LETHAL ORPHAN \\ VIRUS (CEMO) AS A \\ TISSUE CULTURE CONTAMINANT \\ BY \\ DHARAM VIR ABLASHI
}

A THESIS SUBMITTED IN PARTIAL FULFILLMENT OF THE REQUIREMEINTS FOR THE DEGREE OF

MASTER OF SCIENCE

IN

POULTRY SCIENCE

UNI VERSITY OF RHODE ISLAND

1962 
MASTER OF SCIENCE THESIS

OF

DHARAM VIR ABLASHI

Approved:

Thesis committer:-

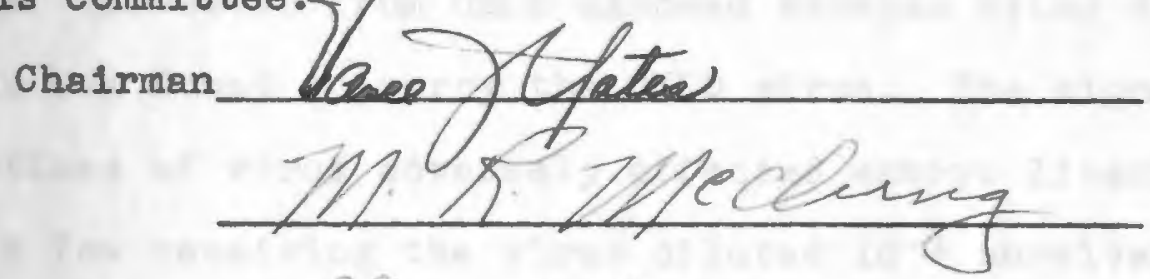

Phipe Lipount Car

Doan of the Graduate School

Shilian N. Shley, berector /

Aquicultural Esperiment station

UNIVERSITY OF RHODE ISLAND 


\section{ABSTRACT}

In each of ten weekly trials, 105 egga from mated White Leghorn hens were divided into sets of 15 eggs each. Yolks of some of these eggs carried CELO antibodies. Before incubation, the various sets of eggs vere inoculated through the air cell into the albumen with decimal dilutions of the virus, 10-1 through 10-5. In each trial two controls were maintained. One set was inoculated with normal allantoamniotic fluid, the other was not inoculated.

AAF harvested from CELO exposed embryos dying during incubation was found to carry the CEIO virus. The higher concentrations of virus adversely affected embryo livability, and only a few receiving the virus diluted $10^{-1}$ survived until hatching. Embryos receiving the virus diluted 10-2 or $10^{-3}$ were also affected, but to a lesser degree. In the rest of the sets only normal embryo mortality occurred during incubation.

The kidneys were removed from the newly hatched chicks and were used as source tissue for cell cultures. Chicks from each of the seven sets were treated separetely. In all cases the cells developed normally, and within 48 to 70 hours a complete sheot was observed. At this time, the starting medium was repleced with a serum-freo maintenance medium. Within 36 to 150 hours of the 
medium change cytopathogenicity developed in all but the control cells. The speed of development varied inversely with the concentration of the virus used to inoculate the eggs before incubation.

Presence of CELO virus in tissue cultures was confirmed by inoculation of embryonating eggs and three-dey-old baby chicks. The development of intranuclear inclusions in chick kidney cell cultures inoculated with the fluids was evident within 48 hours. 
TABLE OF CONTENIS

Page

I. MURODUCTION........................... 7

II. IIEW OF IIIERATURE...................... 10

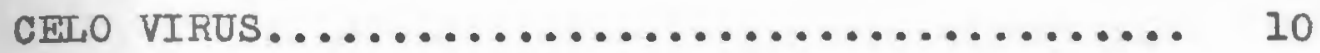

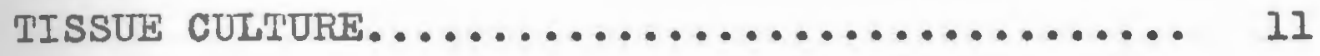

IATENCY AND MASKING.................. 12

RECOVERY OF CONTANIINANTS................ 12

III. MIRIAIS AND METHODS.................. 15

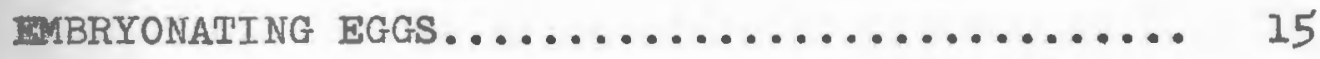

VIRUS (SEED CULTURE) ................... 15

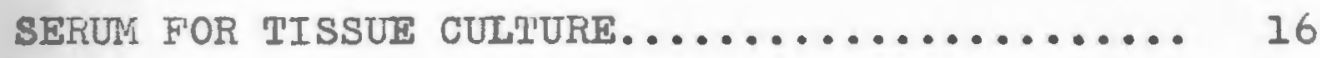

SOURCE AND PREPARATION OF CHICK KIDNEY CELIS... 16

$\triangle G A R$ GEL MEDIUM AND PREPARATION OF AGAR PLATES. 17

PREPARATION OF ANTISERUMS AGAINST CELO....... 18

IXXPERIMENIAI, PROCEDURE (INOCULATION OF EGGS)... 18

REISOLATION OF IHE VIRUS FROM EHBRYONATING EGGS 19

Agar Gel Diffusion Test................ 19

Virus Neutralization Test............... 20

REISOLATION OF THE VIRUS FROM TISSUE CUITURES.. 20

STAINING OF TISSUE CULTURE MICROSILDES....... 21

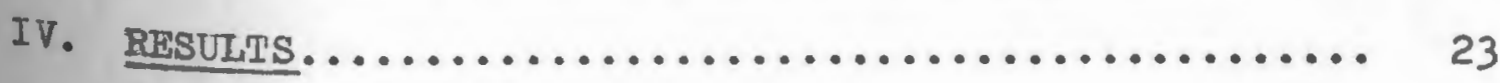

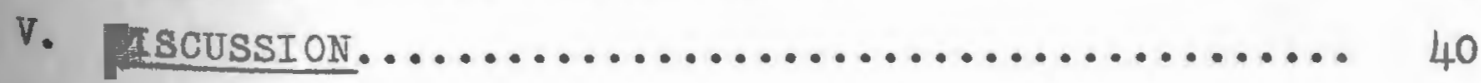

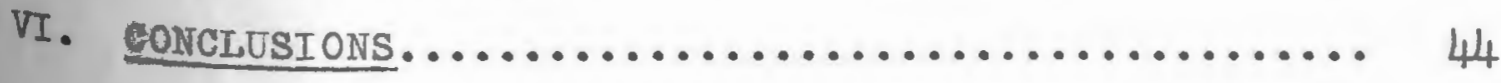




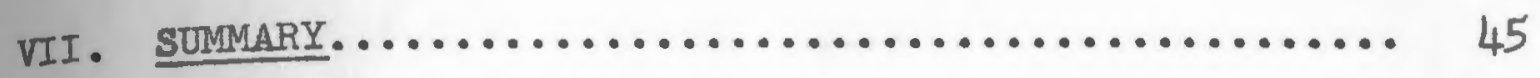

VII. SEROWLEDGNENTS ...................... 46

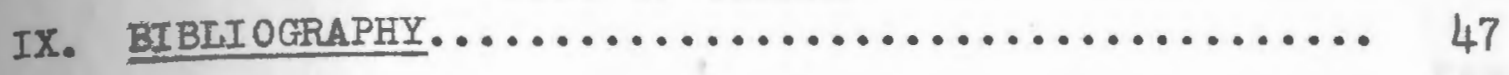

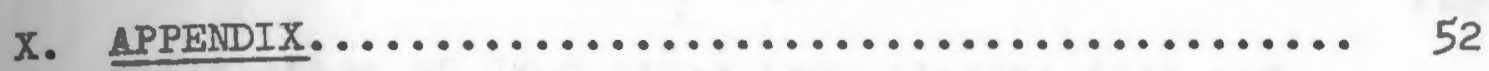


LIST OF TABLES

Page

1. Reisolation of CHUO virus from tissues (AAF and embryo kidney) of eggs exposed before incubation.

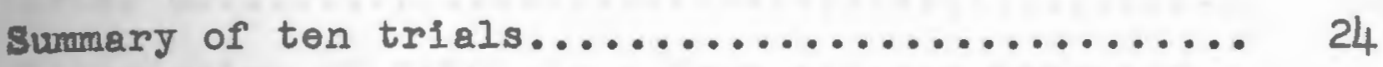

2. Reisolation of CELO virus from tissues (AAF and embryo kidney) of eggs exposed before incubation. Trial 1. 25

3. Reisolation of CEHO virus from tissues ( $A A F$ and embryo kianey) of eggs exposed before incubation.

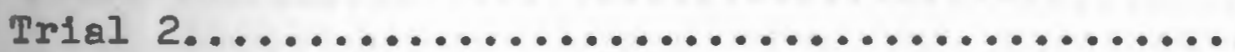

4. Reisolation of CELO virus from tissues (AAF and embryo kidney) of eggs exposed before incubation. Trial $3 . \ldots \ldots \ldots \ldots \ldots \ldots \ldots \ldots \ldots \ldots \ldots \ldots \ldots \ldots$

5. Reisolation of CELO virus from tissues (AAF and cmbryo kidney) of eggs exposed before incubation. Trial 4

6. Reisolation of CELO virus from tissues (AAF and mbryo kidney) of eggs exposed before incubetion. Trial 5 .

7. Reisolation of CELO virus from tissues (AAF and embryo kidney) of eggs exposed before incubation. Trial 6 
8. Roisolation of CELO virus from tissues (AAF and embryo kidney) of eggs exposed before incubation. Trial 7.

9. Relsolation of CELO virus from tissues (AAF and embryo kidney) of eggs exposed before incubation. Trial 8.

10. Reisolation of CELO virus from tissues (AAF and embryo kidney) of eggs exposed before incubation. Trial 9

11. Reisolation of CEIO virus from tissues (AAF and embryo kidney) of eggs exposed before incubation. Trial 10 .

12. Results of intracerebral inoculation of tissue culture isolates into three-day-old chicks........ 


\section{LIST OF FIGURES}

1. Time of CPE in kidney cells from embryos inoculated preincubation with various dilutions of CELO virus. 56

2. Effect of serial tissue passage on CELO virus

isolates.

3. Death time of embryos inoculated with CELO virus

1solated from one-day-old chick kidney cells..... 58

4. Uninoculated one-day-old chick kidney cell

cultures at 24 hours incubation.............. 59

5. Cytopathogenicity at 24 hours incubation in

one-day-old chick kidney cells inoculated

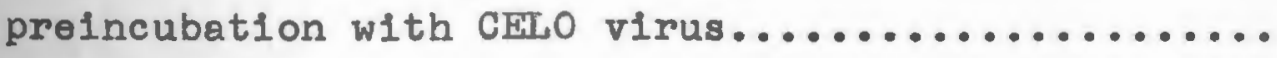

6. One-day-old uninoculated chick kidney cell culture a.t 48 hours incubation.

7. Development of cytopathogenicity in kidney cell cultures at 48 hours of infection............. 60

8. Uninoculated chick kidney cells at 60 hours of incubation.

9. Cytopathogenicity in kidney cell cultures at 60 hours of infection.

10. Jninoculated chick kidney cell cultures at 72 hours of incubation. 
11. Cytopathogenicity in chick kidney cell cultures at 72 hours of infection.....................62 62

12. Intranuclear inclusion bodies produced after 72 hours of infection of CELO virus in one-day-old chick kidney cell cultures..................663

13. Chick from control group I (uninoculated)........ 64

14. Chick from control group II (1noculated with the

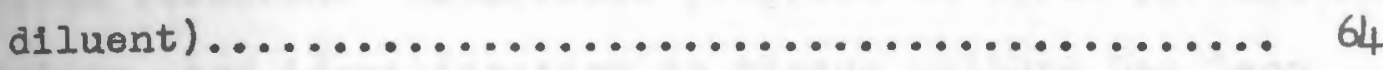

15. Chick inoculated with pooled tissue culture material after five passages in tissue culture showing first stage of nervous symptoms.......... 65

16. Second stage of nervous symptoms............. 65

17. Third stage of nervous symptoms...............66 66

18. Fourth stage of nervous symptoms............. 66 


\section{INTRODUCTION}

During the pest five jears, newer knowledge of mamnalian cell culture has both resulted from and given rise to increased practical and thooretical application in virus research. Remarkable progress in virus propagation, 1solation, and identification in tissue culture has been pointed out in a literature survey by Ross and Syverton (1957).

A biological system maintained under laboratory conditions is subject to contamination by extraneous agents. Living cells, regardless of type, are a potential source of masked and contaminating viruses. Moreover, accidental contamination of cultures in the laboratory is difficult to avoid. Such contaminants have been reported in normal tissue cultures. Hall and Minner (1957) isolated eight now viruses from normal monkey kidney tissue cultures while testing poliomyelitis vaccine for safety. Holmgren and Campbell (1960) demonstrated tissue culture contamination while investigating the conversion of pleuropnoumonia-like-organisms to L-forms. These contaminants and others reported interfered with the multiplication of the original organism. In a two and one-half year period, Hall and Minner (1957) studied a 
seasonal variation in the isolation of tissue culture contaminants. They observed the disappearance of some agents during cortain months of the year. The significance of these results is obscure.

Latent viruses have been reported in tissue cultures from chick embryo cells. Some of these interfered with other viruses (Lennette and Koprowsk1, 1946; Sabin, 1954; Le Bouvier, 1954; Ackerman, 1957; Andrewes, 1942).

CELO virus was identified whlle attempting to isolate laryngotracheitis virus in tissue culture (Chomiak et el., 1961). Hwang ot al. (1959) reported isolation of a CILO-Iike virus during attempts to propagate avian encepholomyelitis (AE) virus in tissue culture. This isolate was closely related serologically to AE virus and avian enteric \#89 virus (Luginbuhl and Ablashi, 1960; Burke et al., 1959). CELO virus has been established as the cause of an Inapparent infection of the chick embryo (Yates and Fry, 1957). Du Bose (1958) isolated CELO strains from uninoculated embryonating chlcken eggs.

Yates et al. (1960) demonstrated that CELO virus can be carried in embryonating eggs and the resulting chicks show no detrimental effects when the virus is introduced before incubation. These findings suggested that at least one method of spread of CELO virus was from the dam to the progeny via the fertilized eggs.

Observations were made to determine if the CELO virus, when introduced into the eggs before incubation, 
would survive and contaminate cell cultures made from tissues of the hatching chicks. 


\section{REVIEW OF LITERATURE}

\section{CELO VIRUS}

The CELO virus has been found in two different host-parasite situations, one as a causative agent of highly fatal respiratory disease in quail and possibly of other birds and, secondly, as the cause of an inapparent infection in chickens. Yates et al. (1954) reported the 1solation of the CELO virus from fertile chicken eggs used for diagnostic studies in a research laboratory. Du Bose (1958), also, isolated CELO virus from fertile eggs. The bens producing the eggs were housed near the area where CELO virus was being studied. Yates and Fry (1957) suggested that the CELO virus was sometimes found in the fertile eggs of apparently normal chickens and that it was revealed when the normal physiology of embryonated eggs was altered elther by inoculation or by some other means. Yates et al. (1960) demonstrated that CELO virus introduced before incubation was carried in the embryonated eggs and in the resulting chickens without producing outward effects. It was further shown that antibodies for CELO virus were cemonly found in chickens and that laboratory diagnosis of infectious bronchitis, laryngotracheltis, avian encephalomyelitis and poultry enteric viruses may be confused by the CELO virus. 
In recent years tissue culture techniques have made significant contributions in the study of mitroorganisms, especially viruses. Cell monolayers on glass, cellophane, or similar substrates are being used more extensively than other cultural methods in viral research. Dulbecco (1952) and Dulbecco and Vogt (1954) demonstrated that cytocidal viruses produced discrete areas of dead cells in monolayer cultures. Madin (1959) reviewed the application of tissue culture in isolation, propagation, and identification of microorganisms. He further discussed the preparation of virus vaccines of human and veterinary importence. Tissue culture has also been used in the study of phagocytosis and in testing toxicity of drugs. Pomerat and Leake (1954) studied carcinogens and the biochemical synthesis of viruses. Initiation of infection by ribonucleic acid (RNA) has been demonstreted in tissue cultures by these authors. Cell cultures have contributed to the study of viral genetics (Hadin, 1959).

There is no doubt that tissue culture systems have facilitated the study of diserses, but at the same time problems have arisen as a result of latent viruses. These have led to confusion, especially in the identification of viruses. 
LATENCY AND MASKING

Latency and masking may confuse the propagation, isolation, and cultivation of viral agents. The latent infection does not show up until it is unmesked by certain mvironmental conditions, $\theta .8$., long incubation period and/or suitable growth medium. Ginsberg (1958) studied latent infections in tissue culture over the period 1956 to 1958. He concluded that latent infections can be regarded as a laboratory artefact, relevant only to the basic nature of the cell-virus interaction. Ackerman (1957) arimentally showed the persistence of virus without replication. He further demonstrated that masking caused by an inhibitor could be reversed, producing a consuming infection of the cells in a culture. This was brought about by the addition of neutral mixtures of virus and antibody. These cells will yield the virus when other techniques are employed.

Bader et al. (1961) malntained cells for two or three deys in penjlalanine or isoleucine deficient mediums which inhibited the synthosis of psittacosis virus. Virus was recovered from these cultures only after the addition of a complete medium. Extension of the interval between infection and adition of complete medium bejond elght days resulted in a permanent disappearance of infectious virus.

\section{RECOVERY OF CONTAMINANTS}

The sudden appearance of an unknown agent in normal tissue cultures confuses the identification of 
certain viral and bacterial agents. The viruses that Hall and Hinner (1957) recovered from normal monkey kidney cultures produced cytopathogenicity and were identified and classified on the basis of their serologic properties. Oninoculated tissue cultures prepared from monkeys with diarheal disease produced eighteen unknown agents. Fundholm et al. (1959) recovered large motile bodies somewhat resembling vibrios from cell cultures prepared from fetal tissues of cattle and sheep. Later, the cultures showed mature Trypanosoma thellerl, and these findings were confirmed by critical morphologic studies.

\section{Fontes et al. (1958) and Sharploss et al. (1958)} reported the cultivation of a viral agent (PRLI2) from the tissues of chickens suffering from avian lymphomatosis. Later, Burmester et al. (1960) studied the pathogenicity of this agent by various routes of inoculation in chicks. They also demonstrated that the virus isolated was antigenically unrelated to lymphomatosis and did not cause the disease. Immunological and serological tests indicated that the starting material contained a mixture of viruses. Macpherson (1960) studied the above agent by the plaque assay method. He found that high titer tissue culture material did not cause the formation of tumors in chicks during a six months observation period. On challenge with Es/4 strain of avian lymphomatosis, the chicks were completely susceptible. It was noted that a high dilution of a pool of normal serum from an Es/4 susceptible flock 
noutralized plaque formation of the (PRII2) virus in tissue cultures. Macpherson stated that the virus he studied was an orphan virus present in the poultry stock.

Rothblat (1960) suggested that PPLO may be present as a contaminant in tissue cultures as a result of (1) PPLO infection of the animal from which the tissue was derived or (2) a breok in aseptic technique when cell lines undergo numerous passages. Holmgren (1960) proposed that the source of infection from PPLO in tissue cells is the conversion of bacterial contaminants to stable L-form by the common use of antibiotics.

Chomlak et al. (1961) isolated an agent while sorially passing laryngotracheitis in tissue culture. It differed from laryngotracheltis virus in production of CPE. The agent was recognized as a CELO virus in the l7th serial passage.

Luginbuhl and Ablashi (1960) showed that the AE virus propagated by Hwang et al. (1959) in chick kidney cells produced a very high level of antibodies in ten werks but on clallenge with an embryo strain of AE the birds developed muscular paralysis and other signs. Later, this tissue culture agent was shown to be serologically related to CELO and avian enteric (\#89) viruses. 


\section{MATERIALS AND METHODS}

\section{EMBRYONATING EGGS}

The eggs used were from Single Comb White Leghorns. A few of these eggs carried yolk antibodies against the CELO agent. The birds were under the care of the Poultry Science Department. The eggs were stored between $55^{\circ}$ and $60^{\circ} \mathrm{F}$. with the relative huridity of approximately 60 per cent. The eggs were inoculated every Friday and then immediately placed in a commercial incubator.

The post-inoculation temperature was about $37.5^{\circ} \mathrm{C}$. with a relative humidity of 86 per cent. On the ninth day the eggs were taken to the laboratory, candled to remove the infertile and dead eggs, and then placed in a laboratory incubator. The embryonating eggs in this incubator were not turned except at the time of candling. The dead embryos were put in a refrigerator to chill for an hour and the AAf was collected to test for the presence of the virus.

\section{VIRUS (SEED CULTURE)}

The stock culture used in the study reported here was the Phelps strain of the CELO virus dated November 21 , 1955. The stock culture was prepared by inoculating nine-day-old embryonating eggs with $0.1 \mathrm{ml}$. of $10^{-1}$ dilution of the virus. The eggs were candled da1ly, and 
all embryos dying early were discarded. Generally 50 to 60 per cent of the eggs died the third day. These and the rest of the egg were chilled at $4^{\circ} \mathrm{C}$. before harvesting. The AAF was hervested aseptically and pooled. It was tested on nutrient agar and in nutrient broth for sterility and was then distributed in five to eight $\mathrm{ml}$. quantities in vacutainers (Becton-Dickenson) and stored in a mechanical freezer at $-20^{\circ} \mathrm{C}$.

\section{SERUM FOR TISSUE CULTURE}

The serum used in the growth medium was obtained from calves in the University of Rhode Island dairy herd. After the serum was collected, it was filtered through a Seltz EKK pad under positive pressure and stored at $-20^{\circ} \mathrm{C}$. SOURCE AND PREPARATION OF CHICK KIDNEY CELLS

Chicks were hatched from eggs which had been inoculated before incubation with a decimal dilution $\left(10^{-1}\right.$ through $\left.10^{-5}\right)$ of the virus. Chicks from control eges which were inoculated with $10^{-1}$ dilution of normal allantoamnionic fluid (AAF) and from uninoculated oggs were also used for the preparation of kidney tissue cultures. The kidneys were removed, minced thoroughly, washed at least three times in phosphate buffered saline (PBS), and then put in trypsin. Ten milliliters of trypsin were used for each pair of kidneys.

The time employed for trypsinization was either one hour at room temperature $\left(18^{\circ}-20^{\circ} \mathrm{C}\right.$.) or 45 minutes at 
$37^{\circ} \mathrm{C}$. The whole mixture was shaken thoroughly until the fragments of kidneys were broken down into a cellular suspension.

The suspended cells were centrifuged at $800-900$ r.p.m. for ten minutes. The supernatant fluid was discarded, and the colls were resuspended in growth medium to obtain a cell concentration of 300,000 per ml. (1.e., 25-30 ml. of growth medium was required per pair of kidneys). The cells were dispensed in bottles in the amount of ten $\mathrm{ml}$. per bottle. A complete sheet of cells was produced in 48-60 hours. At this time the medium had a $\mathrm{pH}$ of 6.8 , and it was replaced by a serum-free maintenance medium. The cells could be maintained for seven to nine days, depending upon the incubation time and temperature and the metabolic activity of the cells.

\section{AGAR GEL, MEDIUM AND PREPARATION OF AGAR PLATES}

The contents of the agar gel modium was : (1) 1so-agar (Difco Laboratory, Detroit, Michigan), (2) sodium chloride, (3) thimerosal (sodium-ethyl-thiosalicylate). Six-tenths per cent of iso-agar and eight per cent sodium chloride were used with $100 \mathrm{ml}$. of demineralized distilled water. After autoclaving the mixture at 15 pounds pressure for 15 minutes, the $p H$ was adjusted to 7.0-7.2 with one normal sodium hydroxide. To control bacterial contamination, 0.0002 per cent of 1.0 per cent thimerosal was added to the agar before pouring the plates (Ablashi et al., 1961). 
The plates were allowed to solidify for an hour at room temperature and then stored at $4^{\circ}$. (at least 24 hours) before use.

PREPARATION OF ANTISERUMS AGAINST CELO

Antiserum against the Pholps strain of CELO virus was prepared in rabbits and chicks (six-weoks-old) by a series of intravenous and intraperitoneal injections. Bvery week, trial bloedings were made until a bigh titer was achioved. After this, the animals and birds were exsenguinated. The serum wes separated, centrifuged, and stored at $-20^{\circ} \mathrm{C}$.

FLPERIMENTAL PFOCEDURE (INOCULATIOH OF EGGS)

The experiment consisted of ten weekly trials. In each trial 105 eggs from mated White Leghorn hens were divided into sets of 15 eggs each. After marking, they were cleaned at the site of the air cell with $1: 1,000$ solution of tincture of Zephiran chloride (Winthrop-Stearns). A hole was punched in the shell over the air sac with a sharponed 20d. spike. The inoculum, 1.e., decimal dilution of virus, $10^{-1}$ through $10^{-5}$ (made in nutrient broth), was deposited in the amount of $0.1 \mathrm{ml}$. per egg using a tuberculin sjringe fitted with a 25 or 26 gauge needle. After inoculation, the eggs were wiped with 95 per cent ethyl alcohol and sealed with glue (DuPont's Duco Cement). They were incubated for nine days in a Jamesway 2940 incubator and then removed to the laboratory incubator. At the time 
of transfer all eggs were candled. Infertile eggs were recorded and discarded, dead ones were recorded and put in the refrigerator for chilling. After chilling, AAF was collected for the agar gel diffusion test as well as virus neutralization tests to detect the CELO virus.

From the ninth day embryonating oggs were candled every day and dead embryos as well as a few live ones from each batch were used for detecting the virus by the two methods mentioned above.

On the 20th dey, the eggs were put in pedigree boxes for hatching. Four or five chicks from each of two sets of virus inoculated eggs and also from one set of controls (inoculated or uninoculated) were taken for the preparation of chick kidney cells in each of the ten trials.

REISOLATION OF THE VIRUS FROM EMBRYONATING EGGS

After the collection of AAF from the embryos, tests for the presence of CELO virus were carried out by the following two methods.

\section{Diffusion Test}

Three parallel lines of holes were cut in the agar plate with a steel tube sharpened at one end. The holes were approximately $1.0 \mathrm{~cm}$. In diameter and $0.5 \mathrm{~cm}$. apart. The holes in the central line were offet $0.5 \mathrm{~cm}$. from the centers of the outside holes. The outside lines contained five boles whereas the central line contained six holes. Two-tenths ml. of AAF from each of the samples was deposited 
in the side holes. Two-tenths $\mathrm{ml}$. of anti-CELO serum, prepared in rabbits or chicks, and anti-AAF serum were placed in the center holes alternately.

The plates were incubated at $37^{\circ} \mathrm{C}$. and examined for the formation of precipitation bands over a period of 120 hours. A lamp was used to 11 luminate the plate from below so as to obtain better visibility.

\section{Neutralization Test}

The test was performed as described by Cunningham (1960). One-day-old chick kidney cell cultures were used. Fluids from ambryonating eggs or tissue cultures were mixed with rabbit or chicken anti-CFLO serum and incubated for one hour at room temperature before inoculating tissue cultures. The readings, 1.e., production of cytopathogenic offect (CPE) in tissue cultures, were recorded up to seven deys. The TCID 50 was computed by the Reed and Muench method (1938).

REISOLAIION OF THE VIRUS FROM TISSUE CULTURES

Tissue culture fluid collected from bottles showing CPE was tested for virus by the following methods: (1) agar gol diffusion, (2) virus noutralization, (3) inoculation Into Eon-day-old embryonating oggs, (4) bird inoculation.

The eggs used for inoculation were from the flock used for the previous study. They were inoculated with $0.1 \mathrm{ml}$. of the tissue culture material by the chorioallantoic sac (CAS) route. Deaths within 48 hours were considered the 
result of something other than virus.

A pool of the tissue culture material from all dilutions was inoculated into one-day-old chick kidney cells and passed serially. Decimal dilutions $\left(10^{-1}\right.$ through $10^{-5}$ ) of the fifth tissue culture passage fluid were inoculated into three-day-old chlcks. For each dilution $0.05 \mathrm{ml}$. was inoculated intracerebrally into each of five chicks. Three control groups were also used. Two groups were inoculated with the same quantity and by the route mentioned above. The first group was inoculated with the diluent, and the second group was inoculated with tissue cultures prepared from the chicks hatched from eggs inoculated with normal AAF. The third group served as uninoculated controls.

All the chicks were housed in the same battery. They were observed daily for the nervous signs described by Yates et al. (1960).

STAINING OF TISSUE CULTURE MICROSLIDES

The microsildes were prepared in Leighton tubes especially designed for this purpose. These microsilides were Irom tissue cultures prepared of chicks hatched from eggs Inoculated with various dilutions of CELO virus, and from AAF inoculated and uninoculated controls. Microsildes showing varlous stages of CPE were fixed and stained according to the following technique, modifled from Johansen (1940): (1) Maintenance medium was discarded from the tubes and microslides were washed with PBS three times. 
(2) Tubes containing the microslides were placed in methyl alcohol for five minutes. (3) Giemsa solution was poured into the tubes and left for 40 minutes at room temperature. (4) Giemsa solution was discarded and the microslides were washed two times with acetone for two and one-half seconds. (5) Microslides were woshed for five seconds in a mixture of equal parts of acetone and xylol. (6) Microslides were cleared in xylol. (7) The stained and cleared microslides were mounted on glass slides with Clerite. (8) They were placed in an incubator to $\mathrm{dry}$ and to remove afr bubbles. 


\section{RESULTS}

Ten trials were carried out to determine if the CELO virus survived when inoculated into eggs before Incubation and contaminated cell cultures made from the tissue of hatching chicks. Table 1 summarizes the individual results presented in Tables 2 to 11.

Embryo mortality was increased in the eggs inoculated with $10^{-1}$ and $10^{-2}$ dilutions of CELO virus. The other dilutions did not adversely affect embryo livability. The chicks that hatched from the CHIO inoculated, as well as from normal AAF inoculated eggs, were clinically healthy.

AAF was collected from embryos dying from the first to the 20 th days as well as from a fow killed between the ninth to the 20th days of incubation. The titer was low In one-half of the AAF samples collected from the embryos that carried $10^{-5}$ dilution of virus. These samples of AAF were noutralized by chick anti-CELO serum. 
TABLE 1.--Reisolation of CELO virus from tissues (AAF and ombryo kidney) of eggs exposed before incubation. Summary of ten trials.

\begin{tabular}{|c|c|c|c|c|c|}
\hline $\begin{array}{l}\text { Virus } \\
\text { Dil. }\end{array}$ & $\begin{array}{l}\text { No. Eggs } \\
\text { Inocu- } \\
\text { lated }\end{array}$ & $\begin{array}{l}\text { No. Eggs } \\
\text { Infertile }\end{array}$ & $\begin{array}{l}\text { \% Dying } \\
\text { During } \\
\text { Incu- } \\
\text { bation }\end{array}$ & $\frac{\text { CELO R }}{\text { From AAFr }}$ & 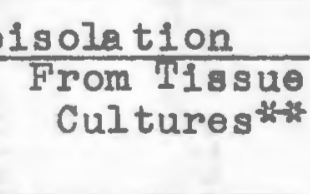 \\
\hline $10^{-1}$ & 150 & 44 & 76.4 & $29 / 29$ & $3 / 3$ \\
\hline $10^{-2}$ & 150 & 38 & 55.4 & $26 / 26$ & $6 / 6$ \\
\hline $10^{-3}$ & 150 & 35 & 22.6 & $20 / 20$ & $4 / 5$ \\
\hline $10^{-4}$ & 150 & 49 & 8.9 & $10 / 10$ & $4 / 4$ \\
\hline $10^{-5}$ & 150 & 42 & 16.7 & $14 / 14$ & $3 / 3$ \\
\hline $\begin{array}{l}\text { AaF } \\
\text { Inocu- } \\
\text { lated } \\
\text { Control }\end{array}$ & 150 & 42 & 4.6 & $0 / 5$ & $0 / 8$ \\
\hline $\begin{array}{l}\text { Uninocu- } \\
\text { lated } \\
\text { Control }\end{array}$ & 150 & 43 & 4.6 & $0 / 4$ & $0 / 3$ \\
\hline
\end{tabular}

* The presence of virus in AAF from embryos dying during incubation was confirmed by the apar gel diffusion test and by the virus neutralization test. Numerator = number of positive results; denominator = number of samples tested.

** The presence of virus in tissue cultures of kidney cells from chicks hatched from inoculated eggs was confirmed by the agar gel diffusion test, the virus neutralization test, inoculation into embryonating eggs and bird inoculation. Numerator = number of positive results; anominator $=$ number of samples tested. 
TABLE 2.--Relsolation of CELO virus from tissues (AAF and embryo kidney) of eggs exposed before incubation. Trial 1.

indoroc

Virug No. No. No. To $10 \quad 11-20$

Dil.\# Eggs Infertilo Embryos

Days Days

Re1solation

\section{CELO}

\section{Tissue Culture}

8

0

0

$---$

\begin{tabular}{lllccccccc}
\hline $10^{-1}$ & 15 & 3 & 12 & 83.3 & 16.7 & $3 / 3$ & $\ldots$ & $\ldots$ \\
$10^{-2}$ & 15 & 4 & 11 & 54.5 & 27.3 & $6 / 6$ & $\ldots$ & $\ldots$ \\
$10^{-3}$ & 15 & 6 & 9 & 11.1 & 44.5 & $3 / 3$ & $\ldots$ & $\ldots$ \\
$10^{-4}$ & 15 & 9 & 6 & 0 & 16.6 & $1 / 1$ & 3 & + \\
$10^{-5}$ & 15 & 8 & 7 & 0 & 14.2 & $1 / 1$ & $\ldots$ \\
AAF & 15 & 3 & 12 & 0 & 0 & $\ldots$ & 5 & $\ldots$ \\
Uninoc- & 15 & 7 & 8 & 0 & 0 & $\ldots$ & $\ldots$ & $\ldots$ \\
ulated & 15 & &
\end{tabular}

CELO

Reisolation $*$ *to

\# Virus diluted in nutrient broth. Inoculum $0.1 \mathrm{ml}$. vis alr cell route.

* Virus 1solations were made by collecting AAF from live embryos or those dying during incubation. AAF was diluted $10^{-1}$ in nutrient broth and inoculated into 7 -day-old chick kidney cells. Numerator $=$ number of isolations. Denominator $=$ number of samples tested.

* Chick kidney colls prepared from hatching chicks.

thet Virus isolation from inoculated chick kidney cells prepared from hatching chicks. TC fluid from bottles showing CPE was used to inoculate 10-day-old embryonating eggs. 
T.ABLE 3.--Re1solation of cELO virus from tissues (AAF and embryo kidney) of eggs exposed before incubation. Trial 2 .

\begin{tabular}{|c|c|c|c|c|c|c|c|c|c|}
\hline \multirow[b]{3}{*}{$\begin{array}{l}\text { Virug } \\
\text { Dil.\# }\end{array}$} & \multirow[b]{3}{*}{$\begin{array}{l}\text { No. } \\
\text { Eggs }\end{array}$} & \multirow[b]{3}{*}{$\begin{array}{l}\text { No. } \\
\text { Infértile }\end{array}$} & \multirow[b]{3}{*}{$\begin{array}{l}\text { No. } \\
\text { Embryos }\end{array}$} & \multicolumn{3}{|c|}{ Embryos } & \multicolumn{3}{|c|}{ Tissue Culture } \\
\hline & & & & \multicolumn{2}{|c|}{ \& Dring } & \multirow[b]{2}{*}{$\begin{array}{l}\text { CELO } \\
\text { Reiso- } \\
\text { lation* }\end{array}$} & \multirow[b]{2}{*}{$\begin{array}{l}\text { Chicks } \\
\text { Used }\end{array}$} & \multirow[b]{2}{*}{$\mathrm{CPE}$} & \multirow[b]{2}{*}{$\begin{array}{l}\text { CELO } \\
\text { Reiso- } \\
\text { lation }\end{array}$} \\
\hline & & & & $\begin{array}{l}\text { To } 10 \\
\text { Days }\end{array}$ & $\begin{array}{l}11-20 \\
\text { Deys }\end{array}$ & & & & \\
\hline $10^{-1}$ & 15 & 8 & 7 & 28.6 & 28.6 & $2 / 2$ & 3 & + & + \\
\hline $10^{-2}$ & 15 & 8 & 7 & 42.9 & $14 \cdot 3$ & $2 / 2$ & $\ldots$ & -- & --- \\
\hline $10^{-3}$ & 15 & 7 & 8 & 0 & 12.5 & $1 / 1$ & 7 & + & + \\
\hline $10^{-4}$ & 15 & 11 & 4 & 0 & 0 & --- & -- & --- & -- \\
\hline $10^{-5}$ & 15 & 8 & 7 & 0 & 0 & $\ldots$ & -- & -- & --- \\
\hline AAF & 15 & 14 & 1 & 0 & 0 & -- & -- & --- & -- \\
\hline $\begin{array}{l}\text { Uninoc- } \\
\text { ulated }\end{array}$ & 15 & 10 & 5 & 0 & 0 & --- & 5 & -- & -- \\
\hline
\end{tabular}

\# Virus diluted in nutrient broth. Inoculum $0.1 \mathrm{ml}$. via air cell route.

* Virus isolations were made by collecting AAF from live ombryos or those dying during incubation. $A A F$ was diluted $10^{-1}$ in nutrient broth and inoculated into 7-day-old chick kidney colls. Numerator $=$ number of isolations. Denominator $=$ number of semples tested.

** Chick kidney cells prepared from hatching chicks.

* Virus isolation from inoculated chick kidney cells prepared from hatching chicks. TC fluid from bottles showing CPE was used to inoculate 10-day-old embryonating eggs. 
'IABLE 4.--Reisolation of cELO virus from tissues (AAF and embryo k1dney) of eggs exposed before incubation. Trial 3.

\begin{tabular}{|c|c|c|c|c|c|c|c|c|c|}
\hline \multirow[b]{3}{*}{$\begin{array}{l}\text { Virug } \\
\text { D11. }\end{array}$} & \multirow[b]{3}{*}{$\begin{array}{l}\text { No. } \\
\text { Eggs }\end{array}$} & \multirow[b]{3}{*}{$\begin{array}{l}\text { No. } \\
\text { Infertilo }\end{array}$} & \multirow[b]{3}{*}{$\begin{array}{l}\text { No. } \\
\text { Embryos }\end{array}$} & \multicolumn{3}{|c|}{ Probzyos } & \multicolumn{3}{|c|}{ Tissue Culture } \\
\hline & & & & \multicolumn{2}{|c|}{ \% Dying } & \multirow[b]{2}{*}{$\begin{array}{l}\text { CELO } \\
\text { ReIso- } \\
\text { lation* }\end{array}$} & \multirow[b]{2}{*}{$\begin{array}{l}\text { Chicks } \\
\text { Used }\end{array}$} & \multirow[b]{2}{*}{$\mathrm{CPE}$} & \multirow[b]{2}{*}{$\begin{array}{l}\text { CEHO } \\
\text { Reiso- } \\
\text { lation }\end{array}$} \\
\hline & & & & $\begin{array}{l}\text { To } 10 \\
\text { Days }\end{array}$ & $\begin{array}{l}11-20 \\
\text { Days }\end{array}$ & & & & \\
\hline $10^{-1}$ & 15 & 9 & 6 & 33.3 & 16.7 & $3 / 3$ & 3 & + & + \\
\hline $10^{-2}$ & 15 & 9 & 6 & 16.7 & 0 & $1 / 1$ & 6 & + & + \\
\hline $10^{-3}$ & 15 & 6 & 9 & 0 & 22.2 & $1 / 1$ & -- & -- & $\ldots$ \\
\hline $10^{-4}$ & 15 & 11 & 4 & 0 & 0 & $\ldots$ & -- & -- & -- \\
\hline $10^{-5}$ & 15 & 7 & 8 & 12.5 & 12.5 & $2 / 2$ & --- & -- & -- \\
\hline AAF & 15 & 10 & 5 & 0 & 0 & $0 / 1$ & 5 & -- & -- \\
\hline $\begin{array}{l}\text { Uninoc- } \\
\text { ulated }\end{array}$ & 15 & 2 & 13 & 0 & 0 & $\ldots$ & $\ldots$ & --- & -- \\
\hline
\end{tabular}

\# Virus diluted in nutrient broth. Inoculum $0.1 \mathrm{ml}$. Via alr cell route.

* Virus isolations were made by coflecting AAF from live embryos or those dying during incubation. AAF was diluted $10^{-1}$ in nutrient broth and inoculated into 7 -day-old chick kidney cells. Numerator $=$ number of isolations. Denominator $=$ number of samples tested.

*w Chick kidney cells prepared from hatching chicks.

**: Virus isolation from inoculated chick kidney cells prepared from hatching chicks. TC fluid from bottles showing CPE was used to inoculate 10-day-old embryonating eggs. 
TABLE 5.--Reisoletion of CELO virus from tissues (AAF and embryo kidney) of egrs exposed before incubation. Trial 4.

\begin{tabular}{|c|c|c|c|c|c|c|c|c|c|}
\hline \multirow[b]{3}{*}{$\begin{array}{l}\text { Virug } \\
\text { Dil.\# }\end{array}$} & \multirow[b]{3}{*}{$\begin{array}{l}\text { No. } \\
\text { Eggs }\end{array}$} & \multirow[b]{3}{*}{$\begin{array}{l}\text { No. } \\
\text { Infertile }\end{array}$} & \multirow[b]{3}{*}{$\begin{array}{l}\text { No. } \\
\text { Embryos }\end{array}$} & \multicolumn{3}{|c|}{ Elbryos } & \multicolumn{3}{|c|}{ Tissue Culture } \\
\hline & & & & \multicolumn{2}{|c|}{ \% Dying } & \multirow[b]{2}{*}{$\begin{array}{l}\text { CELO } \\
\text { ReIso- } \\
\text { lation* }\end{array}$} & \multirow[b]{2}{*}{$\begin{array}{l}\text { Chicks } \\
\text { Used*th }\end{array}$} & \multirow[b]{2}{*}{ CPE } & \multirow[b]{2}{*}{$\begin{array}{l}\text { CEHO } \\
\text { Re1so- } \\
\text { lationsest }\end{array}$} \\
\hline & & & & $\begin{array}{l}\text { To } 10 \\
\text { Days }\end{array}$ & $\begin{array}{l}11-20 \\
\text { Days }\end{array}$ & & & & \\
\hline $10^{-1}$ & 15 & 5 & 10 & 60.0 & 20.0 & $2 / 2$ & 0 & -- & -- \\
\hline $10^{-2}$ & 15 & 2 & 13 & 15.3 & 30.6 & $3 / 3$ & 3 & + & + \\
\hline $10^{-3}$ & 15 & 4 & 11 & 9.1 & 18.2 & $3 / 3$ & 0 & -- & -- \\
\hline $10^{-4}$ & 15 & 4 & 11 & 0 & 0 & $1 / 1$ & 0 & -- & --- \\
\hline $10^{-5}$ & 15 & 5 & 10 & 0 & 20.0 & $1 / 1$ & 5 & + & + \\
\hline AAF & 15 & 2 & 13 & 0 & 7.6 & $0 / 1$ & 7 & --- & --- \\
\hline $\begin{array}{l}\text { Uninoc } \\
\text { ulated }\end{array}$ & 15 & 5 & 10 & 0 & 0 & -- & 0 & --- & --- \\
\hline
\end{tabular}

\# Virus diluted in nutrient broth. Inoculum $0.1 \mathrm{ml}$. via air cell route.

* Virus isolations were made by collecting AAF from live embryos or those dying during incubation. AAF was diluted $10^{-1}$ in nutrient broth and inoculated into 7 -day-old chick kidney cells. Numerator $=$ number of isolations. Denominator $=$ number of samples tested.

ith Chick kidney cells prepared from hatching chicks.

*** Virus isolation from inoculated chick kidney cells propared from hatching chicks. TC fluid from bottles showing CPE was used to inoculate 10-day-old embryonating eggs. 
TABLE 6.--Reisolation of CELO virus from tissues (AAF and embrjo kidney) of eggr exposed before incubation. Trial 5 .

Gimbryos

\section{\% Dring}

\begin{tabular}{|c|c|c|c|c|c|c|c|c|c|}
\hline $\begin{array}{l}\text { Virug } \\
\text { Dil.\# }\end{array}$ & $\begin{array}{l}\text { No. } \\
\text { Eggs }\end{array}$ & $\begin{array}{l}\text { No. } \\
\text { Infertilo }\end{array}$ & $\begin{array}{l}\text { No. } \\
\text { Embryos }\end{array}$ & $\begin{array}{l}\text { To } 10 \\
\text { Days }\end{array}$ & $\begin{array}{l}11-20 \\
\text { Days }\end{array}$ & $\begin{array}{l}\text { CELO } \\
\text { Re1so- } \\
\text { lation* }\end{array}$ & $\begin{array}{l}\text { Chicks } \\
\text { Usedzts }\end{array}$ & CPE & $\begin{array}{l}\text { CELO } \\
\text { Reiso- } \\
\text { lation*H* }\end{array}$ \\
\hline $10^{-1}$ & 15 & 2 & 13 & 69.2 & 7.7 & $4 / 4$ & 0 & $-\infty$ & $\ldots$ \\
\hline $10^{-2}$ & 15 & 2 & 13 & 46.1 & 30.8 & $3 / 3$ & 4 & $-\ldots$ & contaminated \\
\hline $10^{-3}$ & 15 & 1 & 14 & 7.1 & 7.1 & $2 / 2$ & 4 & + & + \\
\hline $10-4$ & 15 & 2 & 13 & 0 & 0 & $1 / 1$ & 4 & + & + \\
\hline $10^{-5}$ & 15 & 5 & 10 & 0 & 30.0 & $2 / 2$ & 0 & -- & --- \\
\hline AAF & 15 & 1 & 14 & 0 & 0 & $0 / 1$ & 7 & --- & -- \\
\hline $\begin{array}{l}\text { Uninoc- } \\
\text { ulated }\end{array}$ & 15 & 2 & 13 & 0 & 0 & $0 / 1$ & 0 & --- & -- \\
\hline
\end{tabular}

\# Virus diluted in nutrient broth. Inoculum $0.1 \mathrm{ml}$. via air cell route.

* Virus isolations were made by collocting AAF from live embryos or those dying during incubation. AAF was diluted $10^{-1}$ in nutrient broth and inoculated into 7-day-old chick kidney cells. Numerator $=$ number of isolations. Denominator $=$ number of samples tested.

* Chick kidney cells prepared from hatching chicks.

*his Virus isolation from inoculated chick kidney cells propared from hatching chicks. TC fluid from bottles showing CPE was used to inoculate 10-day-old embryonating eggs. 
TABLE 7.--Relsolation of CH.O virus from tissues (AAF and embryo kidney) of eggs exposed before incubation. Trial 6.

\section{Enbryos}

V1rus No. No.

No

Eggs

Infortile Embryos
To $10 \quad 11-20$

Days Days

\section{Plssue Culture}

\begin{tabular}{|c|c|c|c|c|c|c|c|c|c|}
\hline $\begin{array}{l}\text { V1rus } \\
\text { D11.\# }\end{array}$ & $\begin{array}{l}\text { No. } \\
\text { Eggs }\end{array}$ & $\begin{array}{l}\text { No. } \\
\text { Infortilo }\end{array}$ & $\begin{array}{c}\text { No. } \\
\text { Embryos }\end{array}$ & $\begin{array}{l}\text { To } 10 \\
\text { Days }\end{array}$ & $\begin{array}{l}11-20 \\
\text { Days }\end{array}$ & $\begin{array}{l}\text { CELO } \\
\text { ReIso- } \\
\text { lation* }\end{array}$ & $\begin{array}{l}\text { Chicks } \\
\text { Usedits }\end{array}$ & CPE & $\begin{array}{l}\text { CELO } \\
\text { Reiso- } \\
\text { lation* }\end{array}$ \\
\hline $10^{-1}$ & 15 & 4 & 11 & 63.6 & 36.4 & $2 / 2$ & 0 & -- & -- \\
\hline $10^{-2}$ & 15 & 2 & 13 & 69.2 & 15.4 & $3 / 3$ & 0 & $-\infty$ & -- \\
\hline $10^{-3}$ & 15 & 2 & 13 & 7.6 & 15.2 & $2 / 2$ & 5 & + & + \\
\hline $10^{-4}$ & 15 & 3 & 12 & 16.6 & 8.3 & $1 / 1$ & 5 & + & + \\
\hline $10-5$ & 15 & 0 & 15 & 0 & 26.6 & $4 / 4$ & 0 & -- & -- \\
\hline $\mathrm{AAF}$ & 15 & 3 & 12 & 0 & 0 & --- & 5 & -- & -- \\
\hline $\begin{array}{l}\text { Uninoc- } \\
\text { ulated }\end{array}$ & 15 & 5 & 10 & 0 & 0 & -- & 0 & -- & -- \\
\hline
\end{tabular}

Chicks Usedists

CPE

CEIO

Reiso-

lation:stox

\# Virus diluted in nutrient broth. Inoculum $0.1 \mathrm{ml}$. Via air cell route

* Virus isolations were made by collecting AAF from live embryos or those dying during incubation. AAF was diluted $10^{-1}$ in nutrient broth and inoculated into 7-day-old chick kidney cells. Numerator $=$ number of 1solations. Denominator $=$ number of samples tested.

*t: Chick kidney cells prepared from hatching chicks.

स*- Virus isolation from inoculated chick kidney cells prepared from hatching chicks. TC fluid from bottles showing CPE was used to inoculate 10-day-old embryonating egga. 
TABLE 8.--Reisolation of CELO virus from tissues (AAF and embryo kidney) of orgs exposed before incubation. Trial 7.

\begin{tabular}{|c|c|c|c|c|c|c|c|c|c|}
\hline \multirow[b]{3}{*}{$\begin{array}{l}\text { Virus } \\
\text { D11.\# }\end{array}$} & \multirow[b]{3}{*}{$\begin{array}{l}\text { No. } \\
\text { Eggs }\end{array}$} & \multirow[b]{3}{*}{$\begin{array}{l}\text { No. } \\
\text { Infertile }\end{array}$} & \multirow[b]{3}{*}{$\begin{array}{l}\text { No. } \\
\text { Embryos }\end{array}$} & \multicolumn{3}{|c|}{ Embryos } & \multicolumn{3}{|c|}{ T1ssue Culture } \\
\hline & & & & \multicolumn{2}{|c|}{ \% Dring } & \multirow[b]{2}{*}{$\begin{array}{l}\text { CELO } \\
\text { ReIso- } \\
\text { lation\% }\end{array}$} & \multirow[b]{2}{*}{$\begin{array}{l}\text { Chicks } \\
\text { Used }\end{array}$} & \multirow[b]{2}{*}{ CPE } & \multirow[b]{2}{*}{ 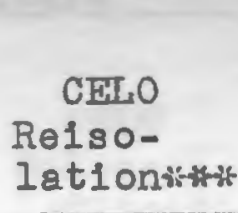 } \\
\hline & & & & $\begin{array}{l}\text { To } 10 \\
\text { Days }\end{array}$ & $\begin{array}{l}11-20 \\
\text { Days }\end{array}$ & & & & \\
\hline $10^{-1}$ & 15 & 3 & 12 & 50.0 & 25.0 & $3 / 3$ & 0 & --- & --- \\
\hline $10^{-2}$ & 15 & 3 & 12 & 16.6 & 25.0 & $2 / 2$ & 4 & + & + \\
\hline $10^{-3}$ & 15 & 5 & 10 & 10.0 & 10.0 & $2 / 2$ & 4 & + & + \\
\hline $10-4$ & 15 & 6 & 9 & 22.2 & 0 & $2 / 2$ & 5 & + & + \\
\hline $10-5$ & 15 & 0 & 15 & 6.6 & 0 & --- & 0 & $\cdots$ & $\cdots$ \\
\hline AAF & 15 & 4 & 11 & 9.9 & 0 & $0 / 1$ & 0 & -- & -- \\
\hline $\begin{array}{l}\text { Uninoc- } \\
\text { ulated }\end{array}$ & 15 & 2 & 13 & 0 & 0 & -- & 5 & --- & -- \\
\hline
\end{tabular}

\# Virus diluted in nutrient broth. Inoculum $0.1 \mathrm{ml}$. via air cell route.

* Virus isolations were made by collecting AAF from live embryos or those dying during incubation. AAF was diluted $10^{-1}$ in nutrient broth and inoculated into 7 -day-old chick kidney cells. Numerator = number of isolations. Denominator $=$ number of samples tested.

*H Chick kidney cells prepared from hatching chicks.

*h Virus isolation from inoculated chick kidney cells prepared from hatching chicks. TC fluid from bottles showing $C P E$ was used to inoculate 10-day-old embryonating $\theta$ ggs. 
TABLE 9.--Reisolation of CELO virus from tissues (AAF and embryo kidney) of ergs exposed before Incubation. Trial 8.

Embroros

\section{\& Dying}

\begin{tabular}{|c|c|c|c|c|c|c|c|c|c|}
\hline $\begin{array}{l}\text { V1rus } \\
\text { D11.\# }\end{array}$ & $\begin{array}{l}\text { No. } \\
\text { Eggs }\end{array}$ & $\begin{array}{c}\text { No. } \\
\text { Infertile }\end{array}$ & $\begin{array}{c}\text { No. } \\
\text { Embryos }\end{array}$ & $\begin{array}{l}\text { To } 10 \\
\text { Days }\end{array}$ & $\begin{array}{l}11-20 \\
\text { Days }\end{array}$ & $\begin{array}{l}\text { CELO } \\
\text { ReIso- } \\
\text { lation* }\end{array}$ & $\begin{array}{l}\text { Chicks } \\
\text { Usedur }\end{array}$ & CPE & $\begin{array}{l}\text { CELO } \\
\text { Reiso- } \\
\text { lation: }\end{array}$ \\
\hline $10^{-1}$ & 15 & 3 & 12 & 75.0 & 0 & $4 / 4$ & 0 & -- & -- \\
\hline $10^{-2}$ & 15 & 3 & 12 & 33.3 & 25.0 & $3 / 3$ & 4 & + & + \\
\hline $10^{-3}$ & 15 & 2 & 13 & 15.4 & 30.8 & $4 / 4$ & 0 & $\ldots$ & --- \\
\hline $10^{-4}$ & 15 & 1 & 14 & 0 & 7.1 & $2 / 2$ & 0 & --- & -- \\
\hline $10^{-5}$ & 15 & 3 & 12 & 0 & 8.3 & $1 / 1$ & 5 & + & + \\
\hline AAF & 15 & 0 & 15 & 0 & 13.3 & $0 / 1$ & 4 & --- & --- \\
\hline $\begin{array}{l}\text { Uninoc- } \\
\text { uleted }\end{array}$ & 15 & 5 & 10 & 0 & 0 & -- & 4 & -- & --- \\
\hline
\end{tabular}

\# Virus diluted in nutrient broth. Inoculum $0.1 \mathrm{ml}$. via air cell route.

* Virus isolations were made by collecting AAF from live embryos or those dying during incubation. AAF was diluted $10^{-1}$ in nutrient broth and inoculated into $7-d a y-01 d$ chick kidney cells. Numerator = number of isolations. Denominator $=$ number of samples tested.

Hit Chick kidney cells prepared from hatching chicks.

*H Virus isolation from inoculated chick kidney cells prepared from hatching chicks. TC fluid from bottles showing CPE was used to inoculate lo-day-old embrjonating eggs. 
TABLE 10.--Reisolation of CBLO virus from tissues (AAF and embryo kidney) of egUs exposed before incubation. Irial 9.

\begin{tabular}{|c|c|c|c|c|c|c|c|c|c|}
\hline \multirow[b]{3}{*}{$\begin{array}{l}\text { V1rus } \\
\text { D11.\# }\end{array}$} & \multirow[b]{3}{*}{$\begin{array}{l}\text { No. } \\
\text { Eggs }\end{array}$} & \multirow[b]{3}{*}{$\begin{array}{c}\text { No. } \\
\text { Infertile }\end{array}$} & \multirow[b]{3}{*}{$\begin{array}{l}\text { No. } \\
\text { Embryos }\end{array}$} & \multicolumn{3}{|c|}{ Dmbryos } & \multicolumn{3}{|c|}{ Tissue Culture } \\
\hline & & & & \multicolumn{2}{|c|}{$\%$ Dring } & \multirow[b]{2}{*}{$\begin{array}{l}\text { CEISO } \\
\text { Re1so- } \\
\text { lation* }\end{array}$} & \multirow[b]{2}{*}{$\begin{array}{l}\text { Chicks } \\
\text { Usedtht }\end{array}$} & \multirow[b]{2}{*}{ CPE } & \multirow[b]{2}{*}{$\begin{array}{l}\text { CELO } \\
\text { ReIso- } \\
\text { lationks }\end{array}$} \\
\hline & & & & $\begin{array}{l}\text { To } 10 \\
\text { Days }\end{array}$ & $\begin{array}{l}11-20 \\
\text { Days }\end{array}$ & & & & \\
\hline $10^{-1}$ & 15 & 6 & 9 & 44.4 & 22.2 & $2 / 2$ & 0 & -- & --- \\
\hline $10^{-2}$ & 15 & 2 & 13 & $15 \cdot 3$ & 23.2 & $1 / 1$ & 4 & + & + \\
\hline $10^{-3}$ & 15 & 1 & 14 & 0 & 7.1 & $1 / 1$ & 0 & --- & -- \\
\hline $10^{-4}$ & 15 & 1 & 14 & 0 & 7.1 & $1 / 1$ & 0 & --- & --- \\
\hline $10^{-5}$ & 15 & 4 & 11 & 0 & 18.1 & $2 / 2$ & 5 & + & + \\
\hline AAF & 15 & 3 & 12 & 0 & 0 & -- & 5 & $-\infty$ & -- \\
\hline $\begin{array}{l}\text { Uninoc- } \\
\text { ulated }\end{array}$ & 15 & 4 & 11 & 0 & 0 & -- & 0 & --- & --- \\
\hline
\end{tabular}

\# Virus diluted in nutrient broth. Inoculum $0.1 \mathrm{ml}$. via air cell route.

* Virus isolations were made by collecting AAF from live embryos or those dying during incubation. AAF was diluted $10^{-1}$ in nutrient broth and inoculated into 7 -day-old chlck kidney cells. Numerator $=$ number of isolations. Denominator $=$ number of samples tested.

* Chick kidney cells prepared from hatching chicks.

然 Virus isolation from inoculated chick kidney cells prepared from hatching chicks. IC fluid from bottles showing CPE was used to inoculate 10-day-old ombryonating oggs. 
TABLE 11.-- Reisolation of cELo virus from tissues (AAF and embryo kidney) of egrs oxposed before incubation. Trial 10.

Embryos

\section{\% Dring}

Virus

D11.\#

No.

No.

No.

To $10 \quad 11-20$

Days

Days

Reiso-

lation*

cks

Useditst

CPE

CELO

Reiso-

letionthest

\begin{tabular}{lllllllll}
\hline $10^{-1}$ & 15 & 1 & 14 & 50.0 & 14.3 & $4 / 4$ & 4 & + \\
$10^{-2}$ & 15 & 3 & 12 & 16.6 & 16.6 & $2 / 2$ & 5 & + \\
$10^{-3}$ & 15 & 1 & 14 & 0 & 7.1 & $1 / 1$ & 0 & $\ldots$ \\
$10^{-4}$ & 15 & 1 & 14 & 0 & 7.1 & $1 / 1$ & 0 & $\ldots$ \\
$10^{-5}$ & 15 & 2 & 13 & 7.6 & 7.6 & $1 / 1$ & 0 & $\ldots$ \\
AAF & 15 & 2 & 13 & 0 & 7.6 & $0 / 1$ & 7 & $\ldots$ \\
$\begin{array}{l}\text { Uninoc- } \\
\text { ulatod }\end{array}$ & 15 & 1 & 14 & 0 & 0 & $0 / 3$ & 0 & $\ldots$ \\
\hline
\end{tabular}

\# Virus diluted in nutrient broth. Inoculum $0.1 \mathrm{ml}$. via air cell route.

* Virus isolations were made by collecting AAF from live embryos or those dying during incubation. AAF was diluted $10^{-1}$ in nutrient broth and inoculated into 7-day-old chick kidney cells. Numerator $=$ number of isolations. Denominator $=$ number of samples tosted.

** Chick kidney cells propared from batching chicks.

* Hirus isolation from inoculated chick kidney cells prepared from hatching chicks. TC fluid from bottles showing CPE was used to inoculate 10-day-old embryonating eggs. 
Agar gel diffusion tests using virus samples against rabbit ant1-CEHO serum developed double, sharp or diffuse precipitation bands after an incubation period of $24-48$ bours at $37^{\circ} \mathrm{C}$. A single sharp well defined band developed in 24-48 hours when chick anti-CELO serum was used. In a few instances AAF collected from eggs inoculated with $10^{-5}$ dilution of CELO virus formed a confusing thick band of precipitate around the hole in which it was placed. In all ten trials, the chick kidney cells from the virus inoculated eggs (Group I) and from chicks of normal AAF inoculated as well as uninoculated eggs (Group II) developed a complete sheet in 48 hours of incubation. The cells from both these groups appeared healthy. After the replacement of growth medium by a serum-free maintenance medium, the following observations were made: (1) In all trials cells prepared from chicks hatched from eggs inoculated with $10^{-4}$ dilution of CELO showed degeneration in 30-36 hours. (2) Cells from $10^{-3}$ dilution chicks showed degeneration after 48 hours. (3) Degeneration patterns in cells prepared from $10^{-5}, 10^{-2}$, and $10^{-1}$ dilutions started after 75,138 , and 150 hours respectively.

In general, 24 hours after the onset of degeneration, the maintenance medium in these tissue cultures had a $p H$ range of $7.2-7.0$. At 36 hours, distinct, scattered dark areas were observed in the sheet of cells. At 48 hours, CPE was very distinct. The cells were reduced in length 
and widtb. The nuclel were enlarged, irregular in shape, and their margins were rough. The pH was 7.0-6.8. After this stage, the cytological changes occurred rapidij. At 60 hours, more than half the cells were gone. The cells appeared round and granular. At 72 hours, only a few cells were left, more than 90 per cent containing nuclel of 1rregular shape. Intranuclear inclusion bodies were distinct when the cells were stained with Giemsa. Various stages of CPE in chick kidney cell cultures are shown in Figures $5,7,9,11$, and 12 .

The second group of cells, prepared from chicks hatched from eggs inoculated with normel AAF as well as uninoculated eggs, were found healthy. A change of pH 7.4 to 7.2 appeared 48 hours after replacement of the growth medium by maintenance medium. The cell sheet was complete with very slight shrinkage in cell length. A slight change in cell length occurred at 60 hours that might have been due to change in pH. Most of the cells were flat, elongated, and thick. The nuclel were round or oval with regular margins and not enlarged. At 72 hours, some of the cells showed increased shrinkage and, at a few places, the cells started peeling off the glass. Photomicrographs of the second group of cells are shown in Figures $4,6,8$, and 10.

The tissue culture fluids from both groups, 1.e., those which showed $\mathrm{CPE}$ and those which did not, were harvested separately after 72 hours. In harvesting, the tissue 
culture bottles were frozen for one hour at $-20^{\circ} \mathrm{C}$., the bottles were partially thawed, and the slush was shaken to dislodge any cells still adhering to the glass.

The material from each group was pooled and

inoculated via the CAS route into ten-day-old embryonating eggs. Mabryos inoculated with AAF from the first group died on the third, fourth, and fifth day. There were variations in the death pattern from dilution to dilution. The pool from the $10^{-1}$ dilution caused deaths at 120 hours, whereas that from the $10^{-2}$ dilution killed at 96 hours. Deaths occurred in 72,80 , and 90 hours from 10-3, 10-4, and $10^{-5}$ dilutions, respectively.

No death occurred in the second (control) group of Inoculated eggs. The tissue culture material collected from the first group was sterile and not toxic. The tissue culture material from the first group was passed serially six times in chick kidney cell cultures (Figure 2). Sorial tissue culture passage of the CELO isolates Increased their pathogenicity for kidney cells. After six passages CPE developed 25 to 40 hours after inoculation with virus isolated from cells of eggs receiving $10^{-1}$ through $10^{-5}$ virus dilutions (Figure 2). On inoculation of this material into ten-day-old embryonating eggs, deaths occurred in 72 to 96 hours (Figure 3). Pools of isolates were neutralized by chick and rabbit anti-CELO serums. Virus titers in these pools were 109.5 and 108.0 in tissue cultures and embryonating eggs, respectively. 
The results of the virus neutralization and titration tests indicated that the isolates were CELO virus.

The results of bird inoculations are summarized in Table 12. 
TABLE 12.--Results of intracerebral inoculation of tissue culture isolates into threo-day-old chicks.

\begin{tabular}{|c|c|c|c|c|c|c|c|c|c|c|c|c|}
\hline \multirow{2}{*}{$\begin{array}{l}\text { Source } \\
\text { Of } \\
\text { Isolate* }\end{array}$} & \multirow{2}{*}{$\begin{array}{l}\text { No. } \\
\text { Chicks } \\
\text { Inoc. }\end{array}$} & \multirow[b]{2}{*}{ Ist } & \multirow[b]{2}{*}{ 2nd } & \multirow{2}{*}{$\begin{array}{l}\text { Days } \\
\text { 3rd }\end{array}$} & \multirow{2}{*}{$\begin{array}{l}\text { After } \\
4 \text { th }\end{array}$} & \multicolumn{2}{|c|}{ Inoculation } & \multirow{2}{*}{$7 \mathrm{th}$} & \multirow[b]{2}{*}{ 8th } & \multirow[b]{2}{*}{9 th } & \multirow{2}{*}{$\begin{array}{l}\text { Per cent } \\
\text { Nervous } \\
\text { Symptoms }\end{array}$} & \multirow{2}{*}{$\begin{array}{l}\text { Per cent } \\
\text { Dying }\end{array}$} \\
\hline & & & & & & $5 \mathrm{th}$ & $6 t h$ & & & & & \\
\hline $10^{-1}$ & 5 & $-\infty$ & $2 d$ & $2 N$ & -- & $1 D$ & $1 D$ & $2 \mathrm{~N}$ & -- & $1 N$ & 100 & 40 \\
\hline $10^{-2}$ & 5 & -- & $2 d$ & $\begin{array}{l}1 d \\
2 N\end{array}$ & $1 \mathrm{~N}$ & $2 D$ & - & $2 \mathrm{~N}$ & - & - & 100 & 40 \\
\hline $10^{-3}$ & 5 & -- & -- & -- & -- & $2 D$ & -- & $1 N$ & - & $1 N$ & 80 & 40 \\
\hline $10^{-4}$ & 5 & -- & - & $4 d$ & $3 N$ & - & $2 N$ & -- & -- & -- & 100 & 0 \\
\hline $10^{-5}$ & 5 & -- & -- & 4d & $3 N$ & - & $2 N$ & -- & -- & -- & 100 & 0 \\
\hline Control & & 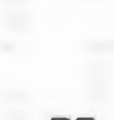 & & 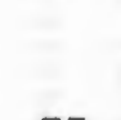 & 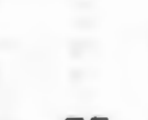 & & - & & & - & & \\
\hline$I, I I, I I I$ & 15 & -- & -- & -- & -- & -- & -- & - & -- & $-\infty$ & 0 & 0 \\
\hline
\end{tabular}

*CEL Isolates were passed serially in l-day-old kidney cells. The fluid from the 5th passage was collected for inoculation into chicks. The inoculum was $0.05 \mathrm{ml}$. per chick.

* Death during 15 day observation period.

$N=$ Nervous symptoms (shaking of head, stretching of neck, reluctance to move and when disturbed runs backward and falls over suddenly on the side).

$\mathrm{d}=$ Dullness and unsteady gait. $\mathrm{D}=$ Death. 


\section{DISCUSSION}

The developing embryo was adversely affected by the higher concentrations of the virus; however, the lethal effect of the virus was considerably reduced when it was introduced prior to incubation. The CELO virus was consistently present in the inoculated eggs through the 19th dey of incubation. The above results could be expected since the virus has been known to survive for 42 days at 37.50C. (Yates, 1960). There was no evidence of virus multiplication.

The chicks that hatched from virus inoculated eggs as well as those hatched from the control groups appeared clinically healthy. The observations did not agree with those reported by Yates et al. (1960). The present Investigation did show the persistence of virus, as it was isolated from the kidney cells harvested from chicks at hatching.

In all the ten trials, the kidney cell cultures of chicks from the uninfected eggs, those inoculated before incubation with normal AAF as well as those which were not inoculated, produced a complete cell sheet. The cells looked normal and healthy. After the starting medium was repleced with a serum-free maintenance medium, the cell sheet 
showed cytopathologie changes which varied in time of apgarance. Melnick et al. (1957) stated that alteration in the composition of the medium may influence markediy the multiplication and cytopathogenicity of animal viruses. The speed of cytopathogenicity development varied inversely with the concentration of the virus used to inoculate the preincubation eggs. The reason for this is unknown. It may be due to the presence of incomplete virus particles which lelayed the development of $\mathrm{CPE}$. It would be interesting to observe whether in some situations the unmasking of the CEL virus could be delayed sufficiently to interfere with the use of the cells in propagation or identification of viruses. The new virus may not grow at all or the CELO virus may only inhibit the activity of the virus in question.

Isolates secured from each viral dilution showed a rapid or gradual change in time of CPE appearance, deponding to some extent upon the source of the virus used in the first passage. On the sixth serial passage all chreloped CPE within 25 to 40 hours. It was interesting to observe that with passage isolates from tissues previously exposed (as eggs) to 10-1 to 10-2 viral dilutions showed a drop in CPE time from 140 to 63 hours and from 131 to 63 hours respectively. The postulated incomplete viral particles could have played a part in these results. Von Magnus (1954) pointed out in his experiments that cells heavily infected with virus often produced incomplete virus, 
which interfered with complete (infective) virus particles. Later he demonstrated that the varying decimal dilutions of influenze PR8 strain showed an increase in hemagglutinin titer with serial passage in embryos. It is evident that incomplete CELO virus particles may have infected cells at the same time as the standard virus particles. The first two serial passages of the $10^{-1}$ and $10^{-2}$ CELO isolates may have carried equal amounts of complete and incomplete particles. The incomplete particles would interfere with the complete (infective) particles and delay CPE. In the later serial passages the amount of incomplete virus particles likely decreased hence the CPE time was shortened considerably. The serial passages of the 10-3 to $10^{-5}$ CEUO isolates were more consistent in CPE time, Indicating that the number of mature viral particles (infective) was higher than the number of incomplete particles (Figure 2).

Photomicrographs of tissue culture infected with the isolates showed intranuclear inclusion bodies. It was suggested by Bunting (1953) that these bodies in the last stages of infection become converted to virus particles and fill the nucleus. Only a few animal viruses produce inclusion bodies in the cytoplasm or nucleus of a cell. The presence of intrenuclear inclusion bodies should be helpful in further differenitating CEIO from other viruses. The inclusions may be Foulgen positive or negative, basophilic or acidophilic and crystalline or non-cryataline. 
43.

All the chicks inoculated with serial decimal dilutions of the fifth tissue culture passage of the isolates kveloped nervous symptoms. There was a difference in the severity and time of appearance of symptoms. Chicks which were used as controls remained healthy and normal. The controls and infected chicks were together for more than 15 days, but no clinical signs developed in the controls. 


\section{CONCLUSIONS}

It is concluded thet the virus behaved as a masked infection in embryonated eggs and in the chicks that hatched from these eggs. The virus which was present in the host (kidney cells) was revealed under the conditions of these trials.

The virus-host relationship demonstrated in this study should be valuable as a research procedure for the investigation of viral latency and interference. 


\section{SUMMARY}

The inoculation of CELO virus into fertile eggs before incubation resulted in embryo mortality only when the inoculum contained a high concentration of the virus. CEL 0 virus was consistently reisolated from allantoamnionic fluid of embryos exposed to the virus prior to incubation. Cytopathogenicity developed in uninoculated tissue culture made from one-day-old embryo kidney tissues of eggs exposed to the CELO virus before incubation. Reisolation of CELO virus from tissue culture was confirmed by serological tests and by inoculation in three-day-old chicks. 


\section{ACKNOWLEDGMENTS}

The author acknowledges with gratitude the help. utended to him by Dr. Vance J. Yates in planning this research project as well as in securing a National Institute of Health Grant for the Study. Appreciation is, 2lso, expressed to Dr. M. R. McClung, Dr. P. I. Carpenter and Dr. A. H. Dardiri for their valuable suggestions.

In addition, the author wishes to thank Miss Sheryl Palmatier for her help in typing, reading, and rearranging the material of this thesis. Thanks are due to Mr. Elot J. Hairr for his valuablo assistance in the photomicrographs.

Last but not the least, gratitude is extended to the nombers of the Animal Pathology Department for their co-operation and assistance during this study. 


\section{BIBLIOGRAFHY}

Ablashi, D. V., Yates, V. J., Chang, P. W., and Fry, D. E. 1961. Study of a chick-embryo-lethal-orphan (CELO) virus by agar gel diffusion test. Avian Dis., 5: 456. dekermann, W. W. 1957. Mechanism of persistent and masked infection in tissue culture. Ann. N. Y. Acad. Sci., 67: 392-402.

Andrewes, C. H. 1942. Interference by one virus with the growth of another virus in tissue culture. Brit. Jour. Exptl. Pathol., 23: 214-220. Bader, J. P., and Morgan, H. R. 1961. Latent viral infection of cells in tissue culture. IX. Abortive infection with psittacosis virus. Proc. Soc. Exptl. Bio. and Med., 106: 311-313.

Bunting, H. 1953. Close-packed array of virus-like particles within cells of a human skin papilloma. Proc. Soc. Exptl. Biol. and Med., 84: 327-332. Burke, C. N., Luginbuhl, R. E., and Jungherr, E. L. 1959. Avian enteric cytopathogenic viruses. I. Isolation. II. Characteristic of a prototype. Avian Dis., 3: 413-419. Burmester, B. R., Sharpless, G. R., and Fontes, A. K. 1960. Virus isolation from avian lymphomas unrelated to Iymphomatosis virus. Natl. Cancer Inst., 24: 1443-1447. 
Chomiak, T. W., Luginbuhl, R. E., and Helmboldt, C. F.

1961. Tissue culture propagation and pathology of CEHO virus. Avian Dis. 5: 313-320.

angham, C. H. 1960. A laboratory Guide in Virology.

Burgess Publishing Company, Minneapolis, Minnesota.

Du Bose, R. T. 1958. The identification and characterization

of a virus isolated from Bob White quail with a

respiratory disease. M. S. Thesis, A. \& M. College of

Texas.

Dulbecco, R. 1952. Production of plaques in monolayer

tissue cultures by single particle of an animal virus.

Proc. Natl. Acad. Sc1., 38: 747-752.

, and Vogt, M. 1954. PIaque formation and

isolation of pure lines with poliomyelitis virus.

Jour. Exptl. Med., 99: 167-182.

Fontes, A. K., Burmester, B. R., Welter, W. G., and Iseler,

P. E. 1958. Growth in tissue culture of cytopathogenic

agent from strain of virus which produces avian

lymphoratosis. Proc. Soc. Exptl. Bio. and Med.,

97: $854-857$.

Ginsberg, H. S. 1958. The significance of the viral carrier state in tissue culture systems. Progr. Med. Virol., 1: $36-58$.

Fall, N. R., and Minner, J. R. 1957. New viral agents recovered from tissue culture of monkey kidney cells. II. Problems of isolation and identification. Ann. N. Y. Acad. Sci., 67: 413-423. 
Holmgren, N. B., and Campbell, W. E., Jr. 1960. Tissue cell culture contamination in relation to bacterial plouropneumonia-like organisms L-form conversion. Jour. Bact., 79: 869-874.

Hwang, J., Luginbuhl, R. E., and Jungherr, E. L. 1959. simplified way to cultivate chick kidney cells and maintain the cultures without serum. Science, 130: 793. Johansen, D. A. 1940. Plant Microtechnique. McGraw-Hill Book Company, Inc., New York.

Le Bouvier, G. L. 1954. Interference and cell protection by poliomyelitis virus in tissue culture. Nature, 174: $649-650$.

Lennette, E. H., and Koprowsk1, H. 1946. Interferences between viruses in tissue culture. Jour. Exptl. Med., 83: 195-219.

Luginbuhl, R. E., and Ablashi, D. V. 1960. The serologic response of chickens inoculated with tissue culture propagated avian encephalomyelitis like-virus.

Proc. A. V. M. A. Meeting, Denver, Colorado. Lundholm, B. D., Johannes, S., and McKercher, D. G. 1959. Drpomosoms theileri as a contaminant of tissue origin in cultures of fetal kidney cells in vitro. VirologJ, 8: $394-396$.

Macpherson, I. A. 1960. Plaque formation by an orphan virus of fowl. Nature, 188: 1213-1214. Madin, S. H. 1959. Tissue culture in veterinary medical research. Advances Vet. Sci. V. Academic Press Inc., New York. 
Volnick, J. L., Hsiung, G. D., Rappaport, C., Howes, D., and Reissing, M. 1957. Factors influencing the proliferation of viruses. Texas Rep. Biol. and Med., 15: $490-533$.

Pomerat, C. M., and Leake, C. D. 1954. Short term cultures for drug assays. Ann. N. Y. Acad. Sci., 58: $1110-1124$.

Roed, L. F., and Muench, H. 1938. A simple method of estimating fifty per cent endpoint. Amer. Jour. Hyg., 27: 493-497.

Ross, J. D., and Syverton, J. T. 1957. Use of tissue culture in virus research. Ann. Rev. Microblol., 11: 459-508.

Rothblat, G. H. 1960. PPLO contamination in tissue culture. Ann. N. Y. Acad. Sc1., 79: 430-432.

sabin, A. B. 1954. Noncytopathogenic variants of poliomyelitis virus and resistance to superinfection in tissue culture. Sci., 120: 357. sharpless, G. R., Defend1, V., and Cox, H. R. 1958. Cultivation in tissue culture of the virus of avian lymphomatosis. Proc. Soc. Exptl. Biol. and Med., 97: $755-757$.

Von Magnus, P. 1954. Incomplete forms of influenze virus. Adrances Virus Res., 2: 59-79. Yates, V. J. 1960. Characterization of the chic|pn-embryo-lethal-orphan (CELO) virus. Ph. D. Thesis, University of Wisconsin, Madison, Wisconsin. 
Yates, V. J., Chang, P. W., Dardiri, A. H., and Fry., D. E. 1960. A study of the epizootiology of the CELO virus. Avian Dis., 4: 500-505.

, and Fry, D. E. 1957. Observations on a

chicken-embryo-lethal-orphan (CELO) virus. Amer. Jour. Vet. Res., 18: 687-690.

, and Wasserman, B. 1954. A preliminary report on an apparently new virus disease of chickens. Proc. Ann. Conf. Lab. Workers in Pullorum Dis. Control, inpaginated. 


\section{APPENDIX}

\section{lens used in Standard Tissue Culture Medium}

(The following alterations were made by the Virus Lab., Dept. of Animal Disease, University of Connecticut, Storrs, Conn., and the Dept. of Animal Pathology, University of Rhode Island, Kingston, R. I.)

\section{te Buffered Saline (PBS)}

In the first four trials of the experiment one ml. of ponicillin and streptomycin was added to $100.0 \mathrm{ml}$. of PBS.

\section{Solution 0.25 per cent (Difco Lab.)}

Trypsin

Hanks IX

$$
\begin{gathered}
0.75 \mathrm{~g} . \\
300.00 \mathrm{ml} \text {. }
\end{gathered}
$$

Sterilized by Seitz EK fllter and stored at $-10^{\circ} \mathrm{C}$.

\section{lanced Salt Solution 10X stock (HBSS)}

Solutions $A$ and $B$ were prepared separately and autoclaved for ten minutes at ten pounds pressure. Solution A

$\begin{array}{lrl}\mathrm{NaCl} & 160.0 \mathrm{~g} . \\ \mathrm{KCl} & 8.0 \mathrm{~g} . \\ \mathrm{MeSO}_{4} \cdot \mathrm{7H}_{2} \mathrm{O} & 4.0 \mathrm{~g} . \\ \mathrm{H}_{2} \mathrm{O} & 800.0 \mathrm{ml} .\end{array}$

The salts were dissolved in $\mathrm{H}_{2} \mathrm{O}$.

$\begin{array}{lr}\mathrm{CaCl}_{2} & 2.8 \mathrm{~g} . \\ \mathrm{H}_{2} \mathrm{O} & 100.0 \mathrm{ml} .\end{array}$


solution B

$$
\begin{array}{lrl}
\mathrm{Na}_{2} \mathrm{HPO}_{4} \cdot 12 \mathrm{H}_{2} \mathrm{O} & 3.04 \mathrm{~g} \cdot \\
\mathrm{HH}_{2} \mathrm{PO}_{4} & 1.20 \mathrm{~g} . \\
\text { Glucose } & 20.00 \mathrm{~g} . \\
\mathrm{H}_{2} \mathrm{O} & 800.00 \mathrm{ml} . \\
\text { Phenol red solution } 0.5 \% & 80.00 \mathrm{ml} .
\end{array}
$$

Solutions A and B cooled at room temperature, mixed, and stored at $4^{\circ} \mathrm{C}$.

amin Hydrolyzate (LAH)

A rive per cent solution in demineralized water was prepared, autoclaved at ten pounds for ten minutes, cooled to room temperature, and $1.0 \mathrm{ml}$. of four per cent $\mathrm{NaOH}$ added to every $100 \mathrm{ml}$.

\section{irrotose}

A five per cent solution in demineralized water was prepared, autoclaved at ten pounds for ten minutes, and then chilled to room temperature. One $\mathrm{ml}$. of four per cent $\mathrm{NiOH}$ was added to every $100 \mathrm{ml}$; the resulting solution was stored at $4^{\circ} \mathrm{C}$.

\section{or Seeding Medium}

$$
\begin{array}{ll}
\text { I. Hanks loX } & 10 \mathrm{ml} . \\
\text { Sterilized demineralized } & \\
\text { distilled water } & 80 \mathrm{ml} . \\
5 \% \text { IHAH } & 10 \mathrm{ml} .
\end{array}
$$


II. Powdered antibiotics as follows:

Penicillin ( $1,000,000$ units)

Streptomycin (1 gram)

Mycostatin (500,000 units)

Dissolved in $5 \mathrm{ml}$. sterilized, demineralized, distilled water; $0.1 \mathrm{ml}$. was added to the above mixture.

III. Sterile $\mathrm{NaHCO}_{3}(7.5 \%)$ : one ml. was added to the mixture of I and II if four per cent $\mathrm{NaOH}$ was used in preparation of five per cent LAH. IV. Calf serum: ten ml. added to the above.

thenance Medium

Hanks 10X

LAH $(5 \%)$

Tryptose (5\%)

$\mathrm{NaHCO}_{3}(7.5 \%) *$

Penicillin, Streptomycin,

Mycostatin (PSM)

Sterile demineralized

distilled water
$10 \mathrm{ml}$.

$10 \mathrm{ml}$.

$10 \mathrm{ml}$.

$1 \mathrm{ml}$.

$0.1 \mathrm{ml}$.

Stirred thoroughly and stored at 4 oc.

Then LAH and Tryptose had one ml. each four per cent $\mathrm{NaOH}$ to $100 \mathrm{ml}$.

* Preparation of PSM is described in Step II of Seeding Medium. 


\section{Giemsa Staining}

Memsa stain (stock solution)

A ten per cent solution was prepared in distilled water. This stock solution was further diluted 1:10 with distilled water for use. 
TIME OF CPE IH KIDNEY LELLS FROM EMRRYOS

INOCULATEDI PREIWCUARTION WTTH VARIC'JS DILUTIONS OF CELO VIRUS

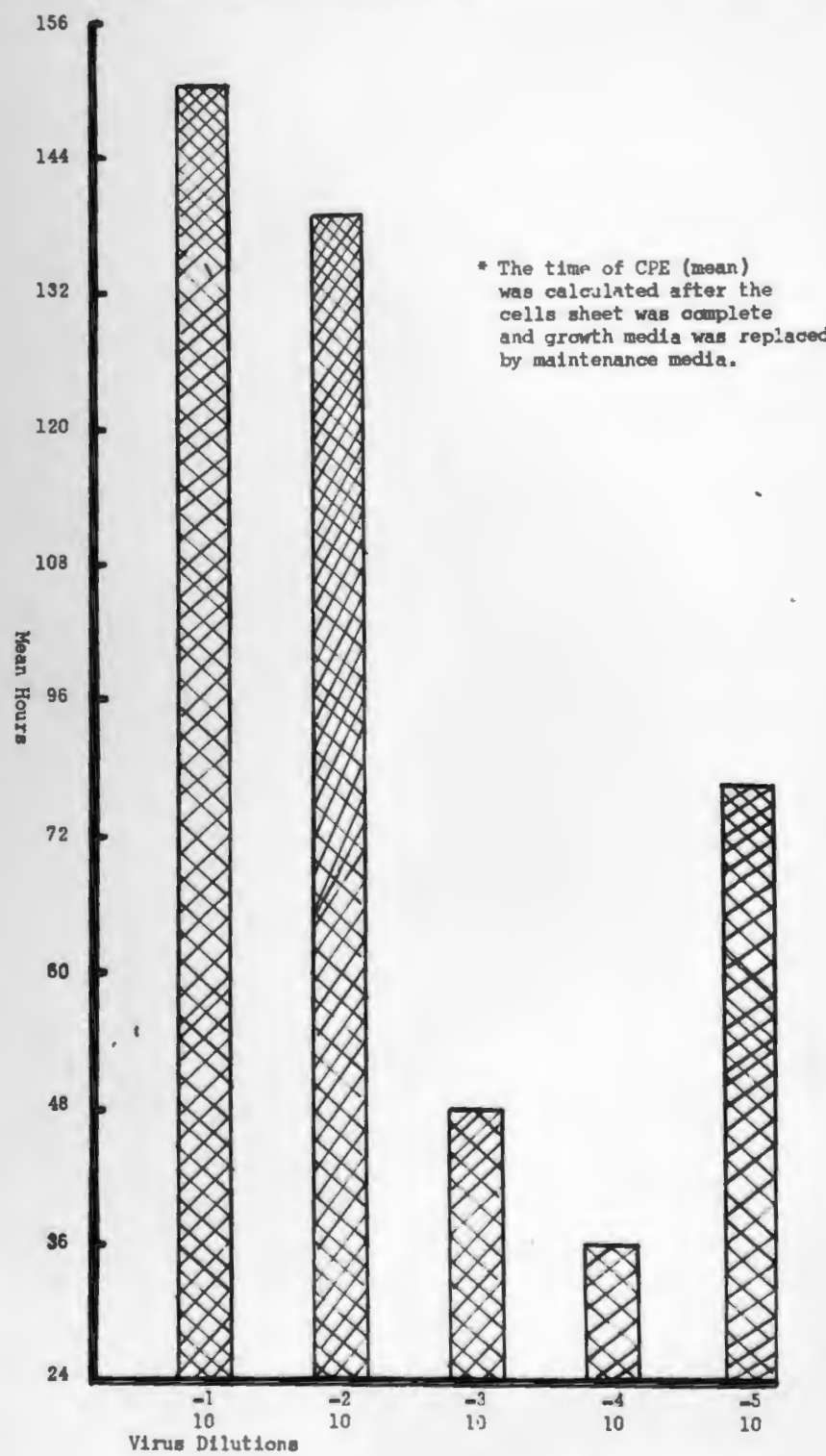

Figure 1. 


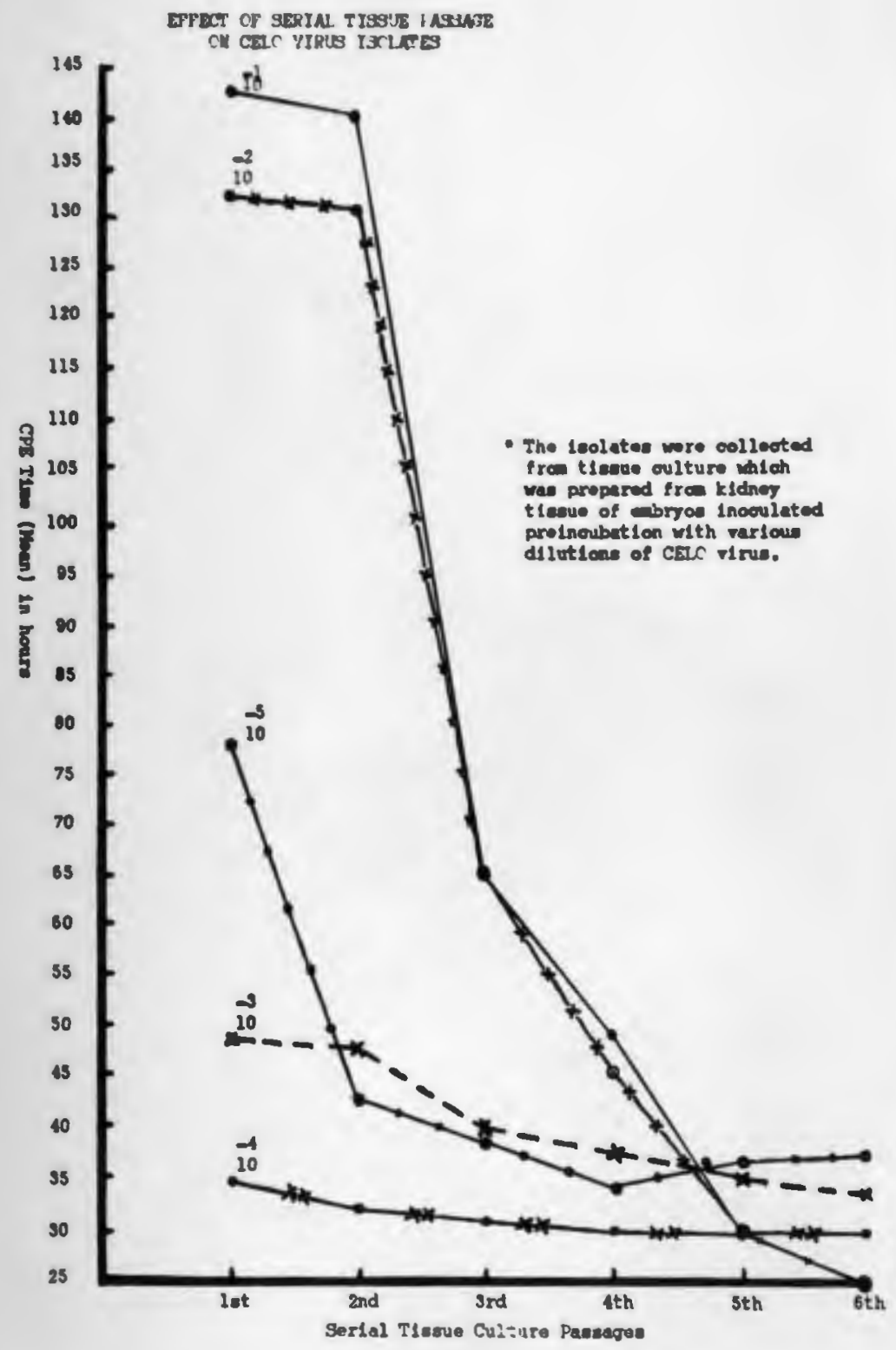

Figure 2. 
DEATH TIME OF EMBRYOS IMOCULATED WITH CELO VIRUS

ISCLLTED FROM OKE-DAY - CLD CHICK KIDNEY CELIS

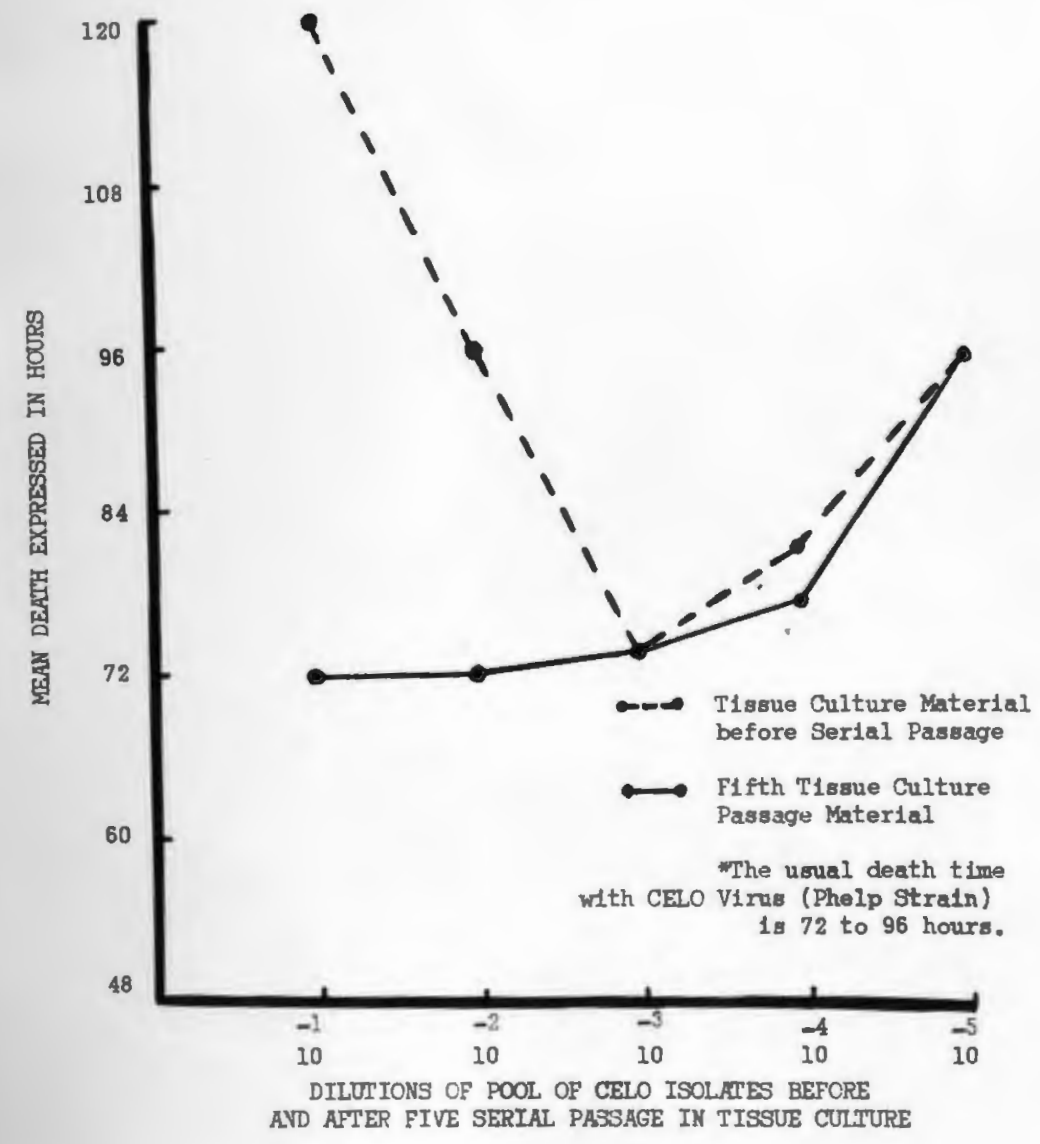

Figure 3. 


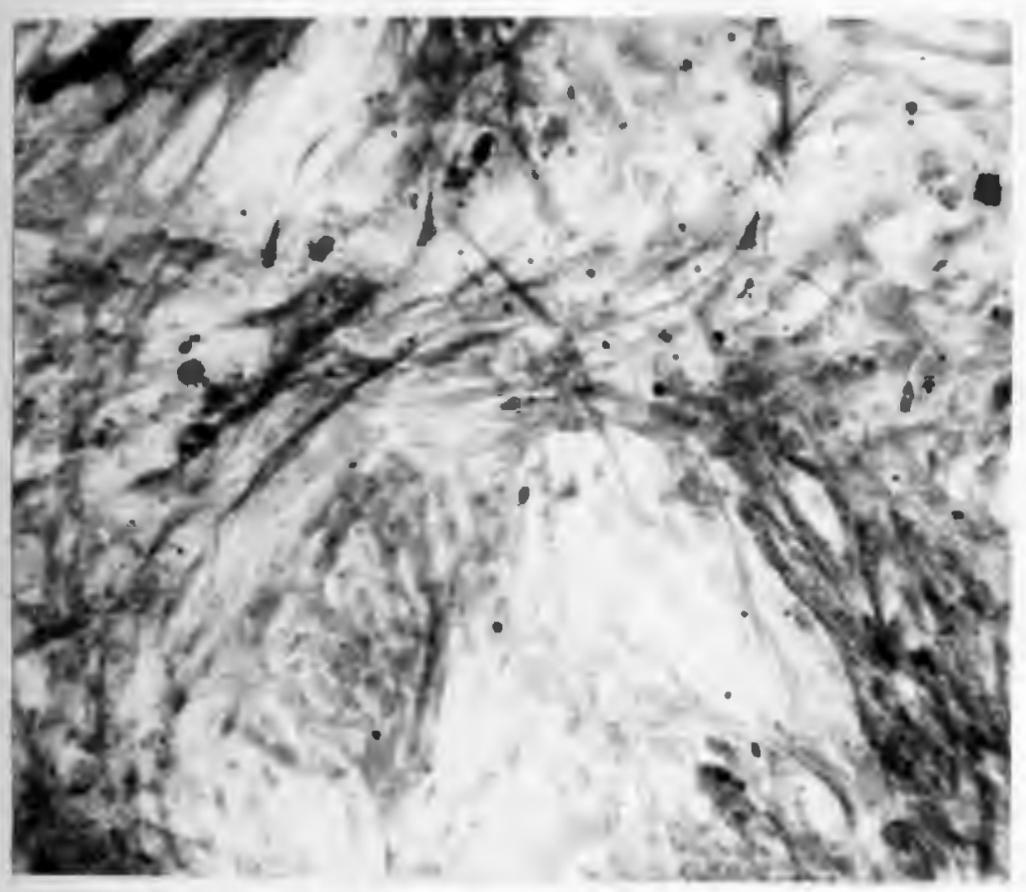

Figure 4.

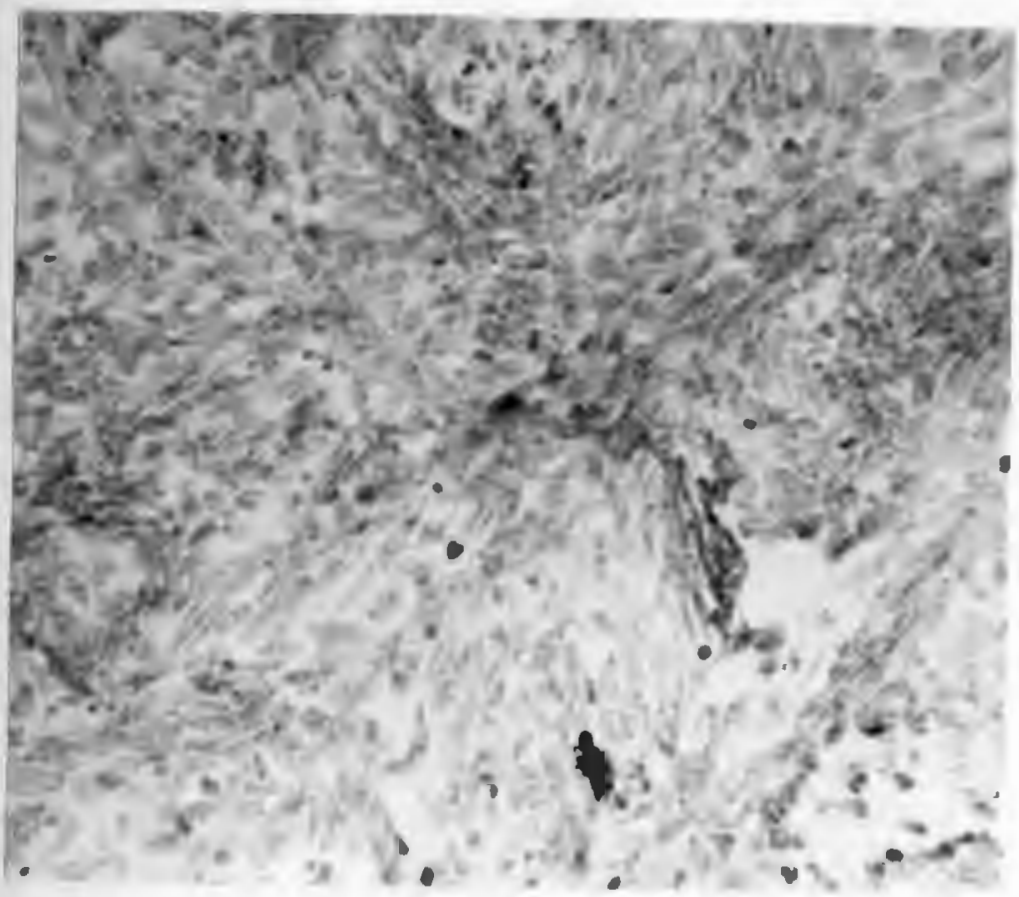

Figure 5. 
Figure 4. Uninoculated one-day-old chick kidney cell cultures at 24 hours incubation.

Figure 5. Cytopatbogenicity at 24 hours incubation in one-day-old chick kidney cells inoculated preincubation with CELO virus. 


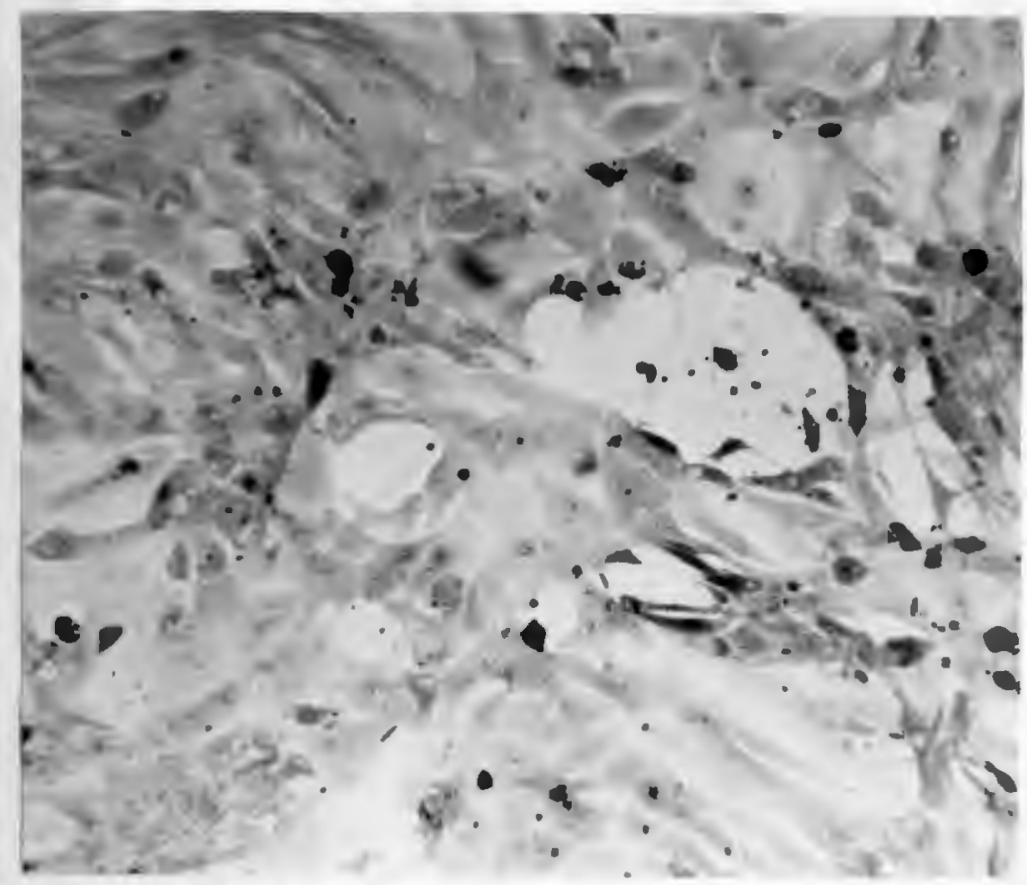

\section{Figure 6.}

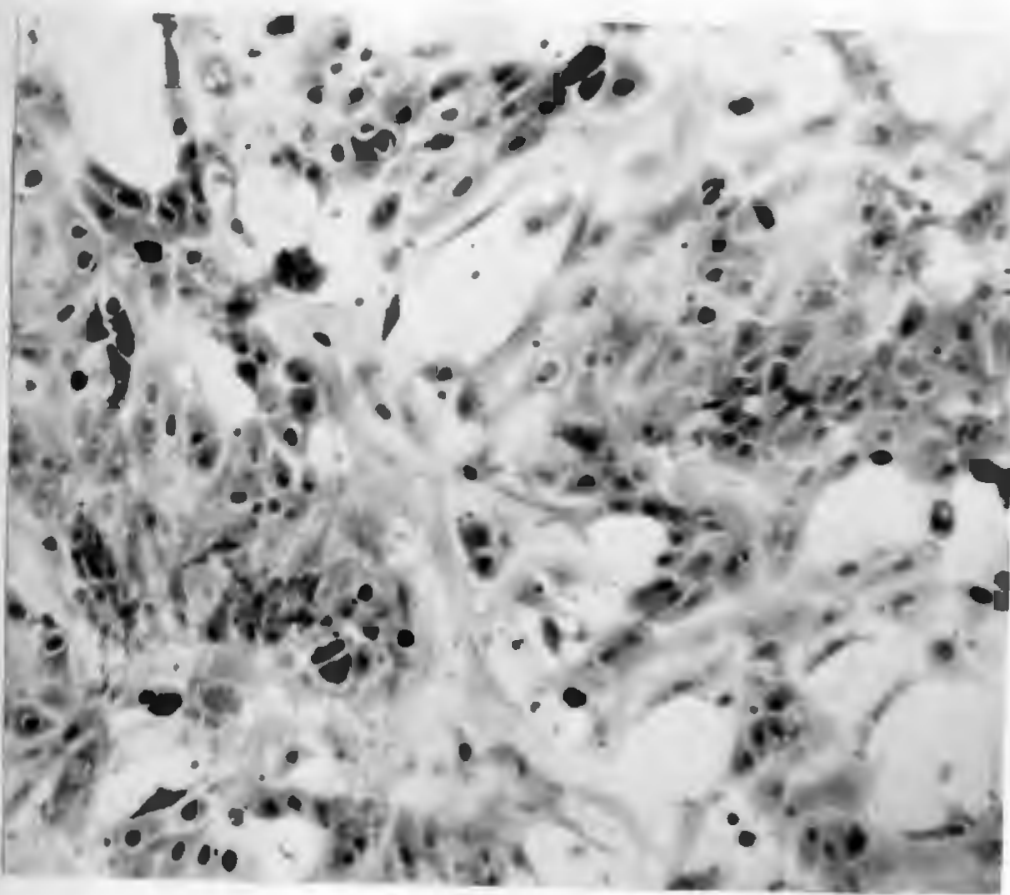

Figure 7. 
Figure 6. One-day-old uninoculated chick kidney cell culture at 48 hours incubation.

Figure 7. Development of cytopathogenicity in kidney cell cultures at 48 hours of infection. 


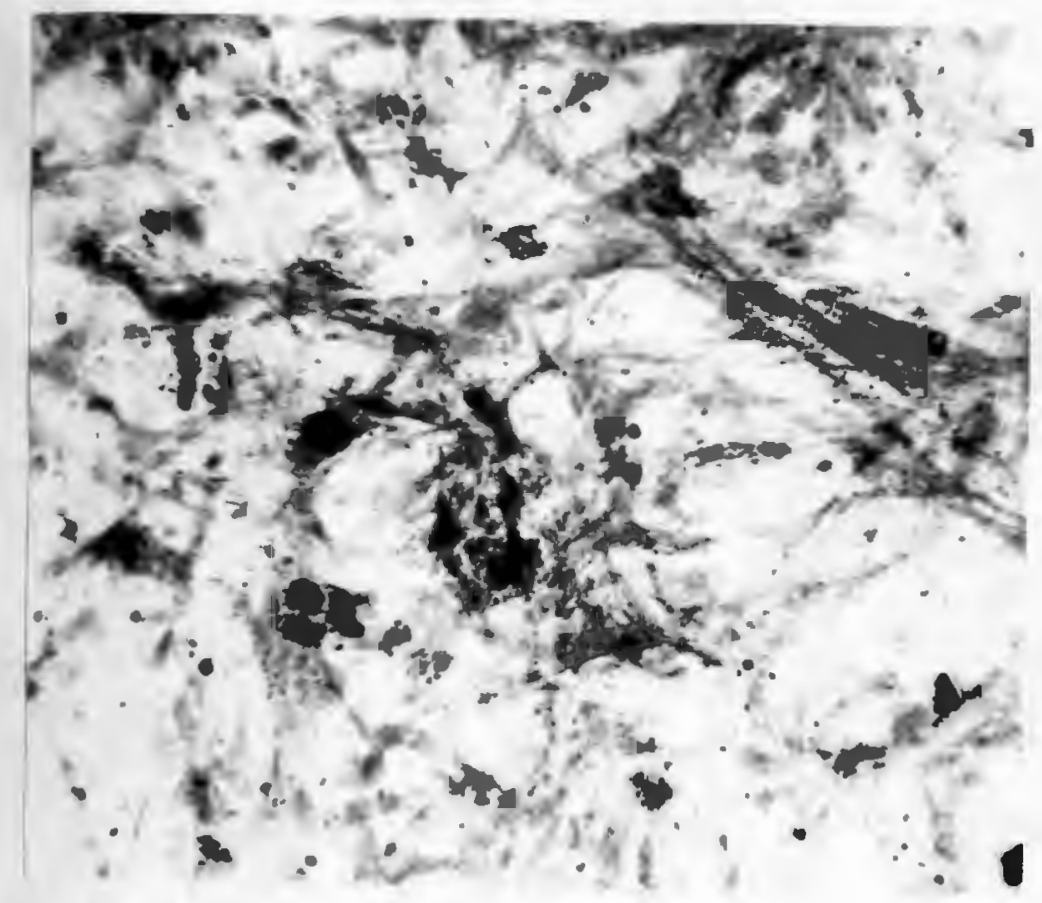

Figure 8.

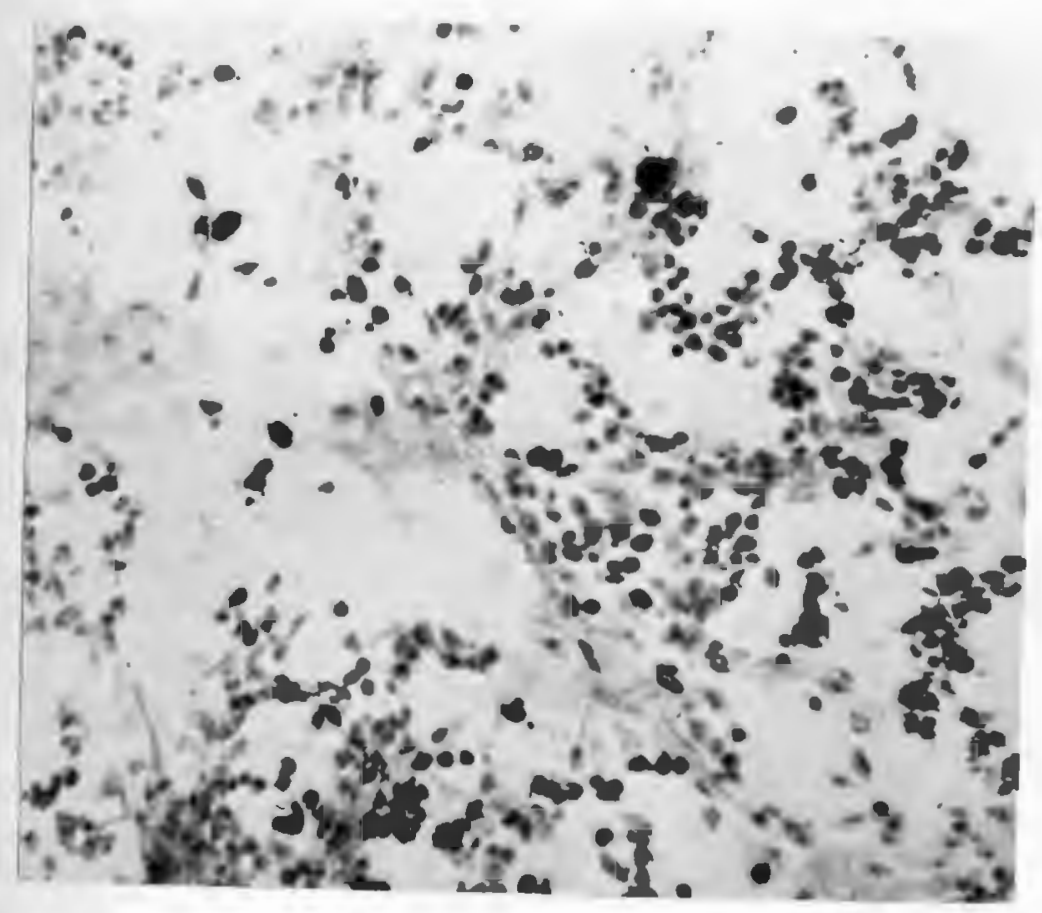

Figure 9. 
Figure 8. Uninoculated chick kidney cells at 60 hours of incubation.

Figure 9. Cytopathogenicity in kidney cell cultures at 60 hours of infection. 
62.
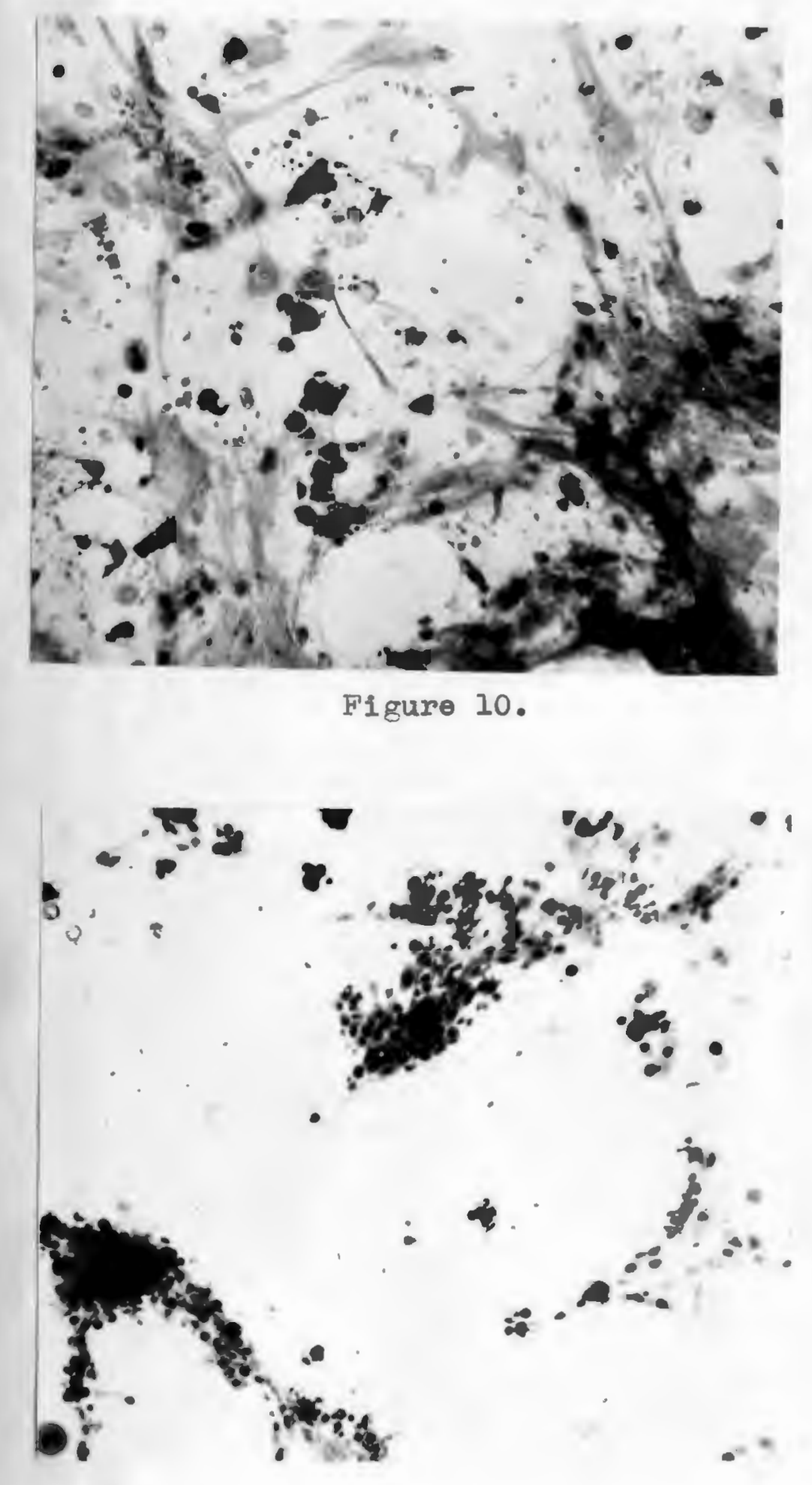

Figure 11. 
Figure 10. Uninoculated chick kidney cell cultures at 72 hours of incubation.

Figure 1l. Cytopathogenicity in chick kidney cell cultures at 72 hours of infection. 
Figure 12. 
Figure 12. Intranuclear inclusion bodies produced after 72 hours of infection of CELO virus in one-day-old chlck kidney cell cultures. 
64.

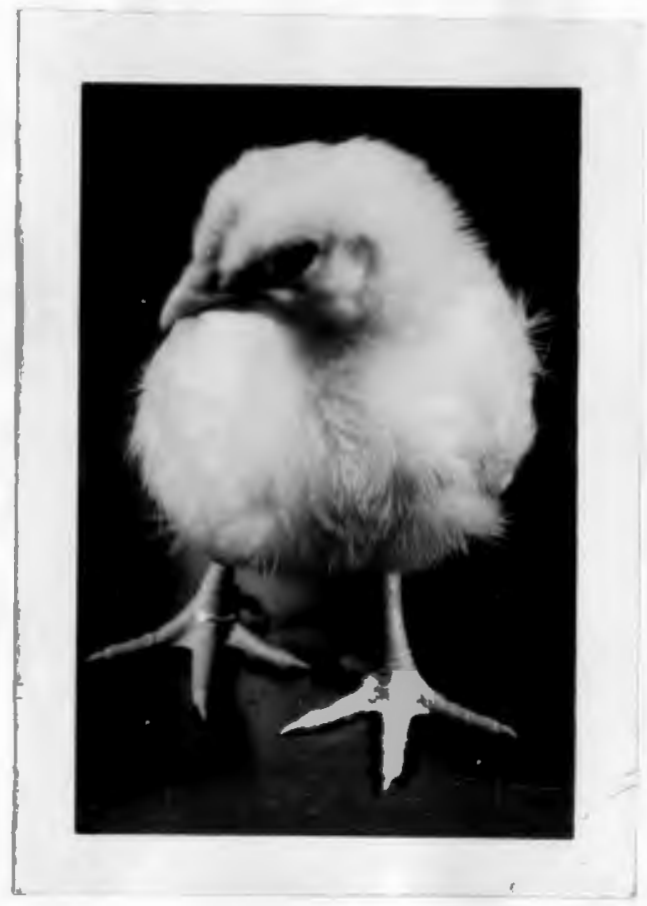

Figure 13.

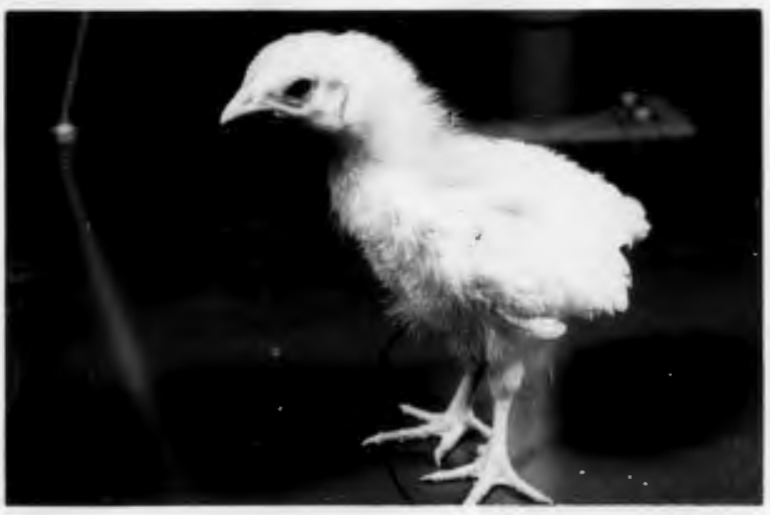

Figure 14. 
Figure 13. Chick from control group I (uninoculated).

Figure 14. Chick from control group II (inoculated with the diluent). 
65.

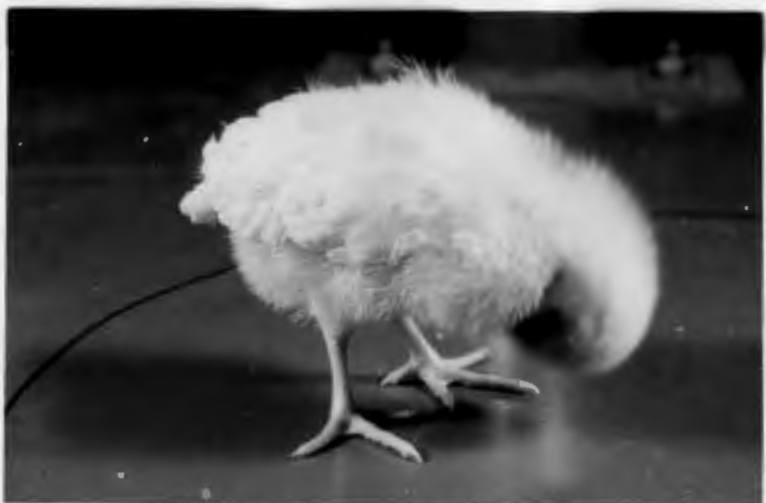

Figure 15.

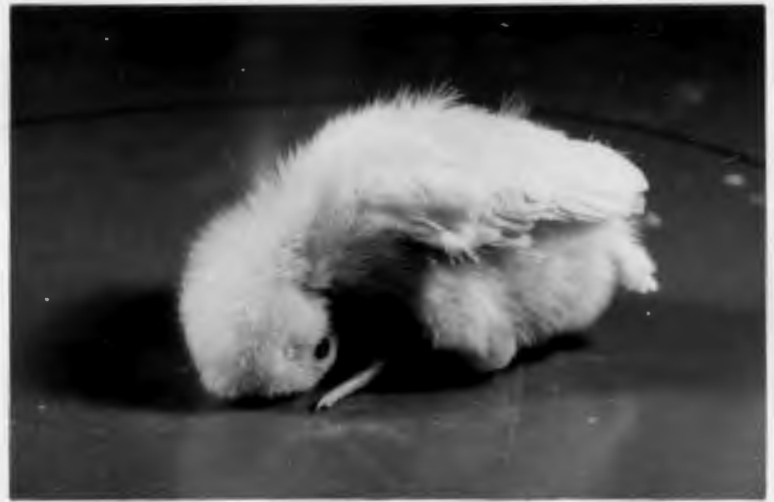

F1gure 16. 
Figure 15. Chick inoculated with pooled tissue culture material after five passages in tissue culture showing first stage of nervous symptoms.

Figure 16. Socond stage of nervous symptoms. 


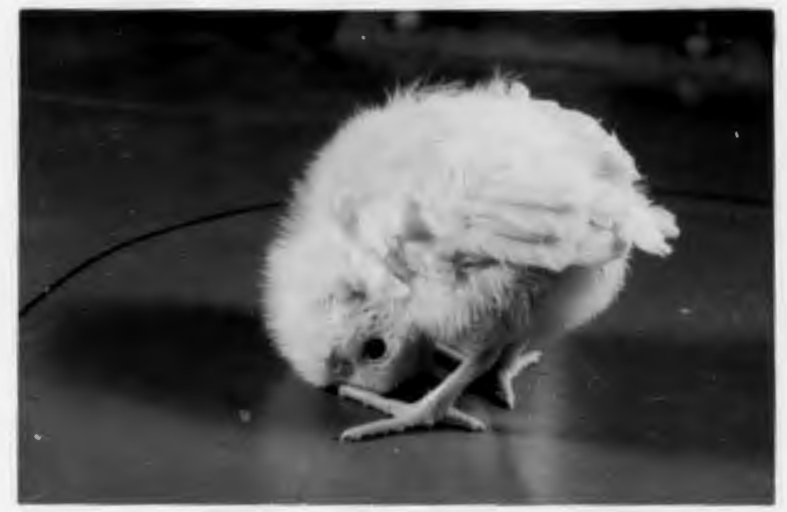

Figure 17.

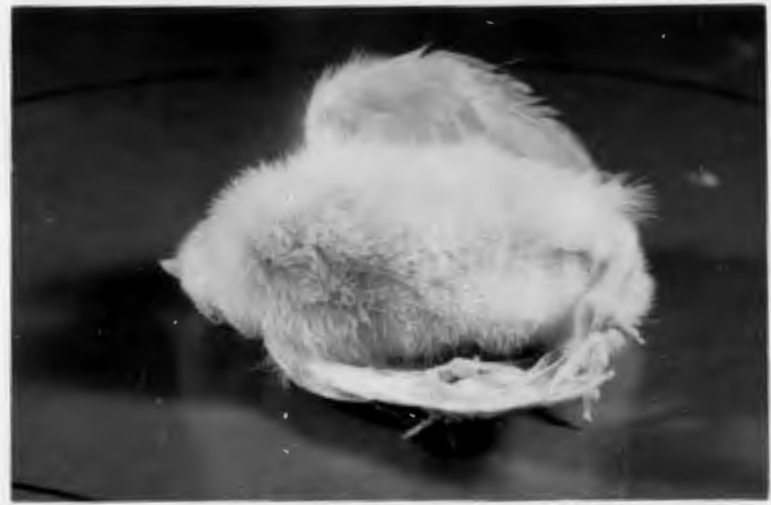

Figure 18. 
Figure 17. Third stage of nervous symptoms.

Figure 18. Fourth stage of nervous symptoms. 